\title{
What the Doctor Thought and Did: Sir James Crichton-Browne (1840-1938)
}

\author{
MICHAEL NEVE and TREVOR TURNER*
}

\section{Introduction}

The long life and diverse activities of James Crichton-Browne (1840-1938), the Scottish-born alienist, neurologist and author, present considerable difficulties in explication. He links the era of Chartism and the appearance, for example, in 1844, of the Vestiges of the natural history of creation, ${ }^{1}$ with the age of psychoanalysis, European war and European fascism. Until the past few years no detailed biographical accounts of his life and work have been available. John Todd and Lawrence Ashworth contributed an essay on his time at the West Riding Asylum at Wakefield, a useful piece that could, however, be said to border on the hagiographical. ${ }^{2}$ Furthermore, their somewhat uncritical and conventional account of Crichton-Browne's achievement at Wakefield, suggested that he created a research-based conjunction between psychiatry and neurology that was not merely original (at least in Britain) but also deeply influential for the subsequent history of post-Darwinian psychiatry. Without wishing to deny his role as an instigator of research and as a man who encouraged others such as David Ferrier, Thomas Clifford Allbutt and John Hughlings Jackson, part of the purpose here is to question the impact of CrichtonBrowne's approach in dealing with the practical tasks facing Victorian alienists. For Crichton-Browne can be construed as more than someone who successfully (albeit temporarily) integrated neurological research with asylum administration. His historical importance rests on his public role as mental hygienist, ${ }^{3}$ Christian evolutionist and proponent (or advocate) of a Carlylean consciousness. ${ }^{4}$

*Michael Neve, MA, PhD, Senior Lecturer in the History of Medicine, Wellcome Institute for the History of Medicine, 183 Euston Road, London NW1 2BE. Trevor Tumer, BA, DHMSA, FRCPsych, MD, Consultant Psychiatrist and Hon. Senior Lecturer, Department of Psychological Medicine, St Bartholomew's Hospital, West Smithfield, London EC1A 7BE.

We gratefully acknowledge the support and comments from colleagues at the Wellcome Units in London, Manchester and Edinburgh, especially W F Bynum. We are indebted to Sarah Gibbs, at St Bartholomew's Hospital, Department of Psychological Medicine, for her help with the manuscript.

${ }^{1}$ Robert Chambers, Vestiges of the natural history of creation and other evolutionary writings, ed. James Secord, University of Chicago Press, 1994. Originally published by John Churchill, London, 1844.

2 John Todd and Lawrence Ashworth, 'The West Riding Asylum and James Crichton-Browne,
1818-76', in G E Berrios and H Freeman (eds), 150 years of British psychiatry 1841-1991, London, Gaskell, 1991, pp.389-418.

${ }^{3}$ For modern reviews of mental hygiene see Nikolas Rose, The psychological complex: social regulation and the psychology of the individual, London, Routledge and Kegan Paul, 1985; Greta Jones, Social hygiene in twentieth-century Britain, London, Croom Helm, 1986; Richard Soloway, Demography and degeneration: eugenics and the declining birthrate in twentieth-century Britain, Chapel Hill, University of North Carolina Press, 1990. Two relevant, near-contemporary texts are William A White The principles of mental hygiene, New York, Macmillan, 1917, and D W La Rue, Mental hygiene, New York, Macmillan, 1927.

4 Crichton-Browne's pervading association with Thomas Carlyle is discussed below in the section entitled 'Carlylean Connections'. 
Independently, the late Janet Oppenheim's 1991 monograph "Shattered Nerves"doctors, patients, and depression in Victorian England ${ }^{5}$ devoted a whole chapter to Crichton-Browne's career. This author has written strikingly on the variety of his psychiatric interests and pronouncements, such as phrenology and the education of young children, his particular eugenical fantasies and fears of racial degeneration, his hostility to hypnotism as a technique and his opposition to Freudianism. However, she does seem to have underestimated the full force, some of it humane, some of it cruel, of CrichtonBrowne's optimism. This optimism can be contextualized only by analysing the details of his day-to-day work and by considering his mental hygienism in full. Much further work is required, particularly on his time as the Lord Chancellor's Visitor in Lunacy, and the paucity of family papers and other archival sources is unfortunate. ${ }^{6}$

The heart of James Crichton-Browne's career lay in the second half of the reign of Queen Victoria, an era which coincided with the realization that the hopes of the asylum as a reform institution, with reasonable levels of curative success, were beginning to falter. Thanks to the work of Andrew Scull, D J Mellett and Michael Clark, ${ }^{7}$ the debates and the difficulties of the second half of the century have begun to be understood. Turner has indicated the escalating gloominess of many of Henry Maudsley's pronouncements on insanity, and the distance that Maudsley put between himself and the crowded wards of the post- 1845 public asylum. ${ }^{8}$ Maudsley stood darkly for pessimism, with a view that hereditarian fate was a hard one to escape, especially in the context of mental illness. As James Crichton-Browne himself recounted, in 1920, their paths "diverged spiritually", because Maudsley "abandoned the teleological platform on which we both started and advanced into scientific materialism and agnosticism where I could not then follow him". The relative optimism of John Conolly's generation appears to have given way, remarkably quickly, to serious doubts, doubts merging with the sad, degenerationist parade of sub-speciating humanity that had been set out by the neo-Thomist French alienist, B A Morel, in his Treatise on degenerations of $1857 .{ }^{10}$ Whether or not Maudsley's materialist gloom can be seen as typical or influential or even fortifying, will be answered by future research into the biographies of other high (or late) Victorian medical psychologists (e.g., J C Bucknill, Lockhart Robertson, and Daniel Hack Tuke). ${ }^{11}$ The

\footnotetext{
5 Janet Oppenheim, "Shattered Nerves"doctors, patients, and depression in Victorian England, New York, Oxford University Press, 1991, pp.54-78.

${ }^{6}$ See LCO 9.5, 11.2 and 11.3 in the Public Records Office (P.R.O.) at Kew for relevant material.

${ }^{7}$ Andrew Scull, Museums of madness, London, Allen Lane, 1979; D J Mellett, The prerogative of asylumdom: social, cultural, and administrative aspects of the institutional treatment of the insane in nineteenth-century Britain, New York and London, Garland, 1982; Michael Clark, 'The rejection of psychological approaches to mental disorders in late 19th century British psychiatry', in A Scull (ed.), Madhouses, mad-doctors, and madmen, London, Athlone Press, 1981, pp. 271-312.

8 Trevor Turner, 'Henry Maudsley: psychiatrist, philosopher and entrepreneur', in W F Bynum, $\mathbf{R}$
}

Porter and M Shepherd (eds), The anatomy of madness, vol. 3, The asylum and its psychiatry, London, Routledge, 1988, pp.151-89.

9 James Crichton-Browne, 'The first Maudsley lecture', J. ment. Sci., 1920, 66: 199-225.

10 B A Morel, Traité des dégénérescences physiques, intellectuelles, et morales de l'espèce humaine, Paris, 1957. The only useful English version (an abbreviated translation) is to be found in the Journal of Psychological Medicine and Mental Pathology, 1857, 10:159-208.

11 For example see Edward Renvoize, 'The Association of Medical Officers of Asylums and Hospitals for the Insane, the Medico-Psychological Association, and their Presidents', in Berrios and Freeman (eds), op. cit., note 2 above, pp.29-78. Work on this topic by Andrew Scull is forthcoming. 
career of James Crichton-Browne, by linking that era with the subsequent world of Freud, the Great War and the long afternoon of post-Victorian unease, should also clarify these questions.

Of first importance was W A F Browne (1805-1885), James's father. This eminent Scottish alienist trained at Edinburgh (qualifying in 1826), was appointed Medical Superintendent to Montrose Asylum (1834), and published his lectures, What asylums were, are, and ought to be, in $1837 .^{12}$ This exposition of what asylums could really be and what they could really do, not only displayed Browne's remarkable administrative skill, but attracted the attention of the rich widow, Mrs Elizabeth Crichton and led to his appointment (1838) at the Crichton Royal Hospital in Dumfries, and eventually saw Browne become, in 1857, a Commissioner for Lunacy in Scotland. As well as studying with Esquirol in Paris in the early 1830s, W A F Browne was strongly committed, from his student days, to the Scottish version of phrenology as laid out by George (for whom he acted as assistant) and Andrew Combe. ${ }^{13}$ Though described recently-incorrectly in our opinion-as militant, radical and anti-clerical, ${ }^{14}$ such politics were not necessarily an obstacle to a well-connected career in early Victorian Scottish psychiatry. But, even if phrenology had its explanatory limits, which towards the end of his life W A F Browne may have believed was the case, ${ }^{15}$ it formed the central theme of his understanding of mental disorders.

It also remained an essential context for the neurological bent of his son, James. In studying the career of James Crichton-Browne, the historical investigations of Cooter and Clarke and Jacyna can be usefully extended. ${ }^{16}$ For he derived from his father an absolute belief that phrenological discourse had been the historical pre-condition for a psychiatry that was scientific, brain-based, attentive to natural law, and which could educate both alienists and students of the subject as to how to differentiate between healthy and unhealthy cerebral activity. Thus in 1924 he described how the phrenologists had "battled for basic principles now unimpeachable". ${ }^{17}$ Since the brain was the "organ of the mind", he insisted that "we are all phrenologists today-phrenologists of the new school-we have come to accept all the cardinal principles upon which the phrenologist insisted". In his view, brains could be exercised, could be nurtured, could be damaged: above all, in the early career of James Crichton-Browne, brains could be opened up and looked at, their gyri delineated, their densities measured. Brains (and the analogy is not far-fetched) like drains, could get blocked up, collect residues, and set up repetitive patterns. With an

12 W A F Browne, What asylums were, are, and ought to be, Edinburgh, Adam and Charles Black, 1837.

${ }^{13}$ Sir James Crichton-Browne, The story of the brain. The Henderson Trust Lectures No. II, Edinburgh, Oliver \& Boyd, 1924, p.1.

14 Adrian Desmond and James Moore, Darwin, London, Michael Joseph, 1991, pp.31-3.

15 See Andrew Scull, The asylum as Utopia: $W$. A. F. Browne and the mid-nineteenth-century consolidation of psychiatry, London, Tavistock/ Routledge, 1991, pp.xxvi-xxvii. As Scull points out in his introduction, the early influence of phrenology failed to maintain itself by the time of Browne's publishing his lectures in 1837.

${ }^{16}$ Roger Cooter, 'Phrenology and British alienists, ca. 1825-1845', in A Scull (ed.), op. cit., note 7 above, pp.58-104, and Roger Cooter, The cultural meaning of popular science: phrenology and the organization of consent in nineteenth-century Britain, Cambridge University Press, 1984, and for neurological developments see Edwin Clarke and $\mathrm{L}$ $\mathrm{S}$ Jacyna, Nineteenth-century origins of neuroscientific concepts, Los Angeles and London, University of California Press, 1987, which concentrates on the first half of the nineteenth century.

${ }^{17}$ Crichton-Browne, op. cit., note 13 above. 


\section{Michael Neve and Trevor Turner}

understanding of particular tenets of mental hygiene, this unhappy history of constriction and malfunction might be ended. Thus one of the most interesting aspects of Sir James Crichton-Browne, the boy from Dumfries, the "Queen of the South", was his belief in epiphanies, in mysterious surges of cerebral health and insight, a belief, one might say, in recovery. ${ }^{18}$

In essence, therefore, the shadow of the Combes falls across the work of both Brownes, father and son, as phrenology relocated into neurology, and as degenerationist, Maudsleyan philosophy collapsed into pessimism. Pace Cooter, and Clarke and Jacyna, it is not even necessary in tracing phrenology's influence to argue over whether the brain is a mediating organ for the expression and promulgation of ideas on social value and social health, although Cooter's vision of a bourgeois iron cage that constitutes those values still causes considerable explanatory problems. ${ }^{19}$ The brain was, for James Crichton-Browne, the primary and essential site for the expression of concepts of health, of differential capacity between the sexes, and of pathology. He could even describe his "own department" of medicine as neurology when exhorting medical students in the 1890s, and the great sweep of a Scottish idea of cerebral natural law, and the ways to understand and utilize it, do indeed, Chambers-like, surge through his mature work. ${ }^{20}$

A second determining life event occurred in 1875, when he was appointed Lord Chancellor's Visitor in Lunacy, a post that required him to move from the West Riding Asylum to London, and removed him from the workaday world of asylum administration and asylum-based neuropathology. From 1876 onwards, Crichton-Browne visited Chancery lunatics in their lodgings or their asylums on a national basis, reporting back to the Chancery Masters in Lunacy, usually at monthly meetings. He also became a London society figure; a speaker; a lecturer; a treasurer and vice-president of the Royal Institution in Albemarle Street; ${ }^{21}$ an essayist. The record merely of the British Medical Journal suggests that he was ubiquitously busy. More importantly, the nature of his social world and his writing changed. From the repetitive particulars of the research laboratory and the West Riding Lunatic Asylum Medical Reports, he debouched into the broad generalizations of the popular moralist.

Indeed, removed from this milieu, it is quite difficult to follow him closely into the actual world of the Lord Chancellor's Visitorship, for archival and other reasons. ${ }^{22}$ But, during this part of his life, especially during the period 1880 to the First World War, he was able to distil an influential public philosophy. Above all, he proposed that the lessons of neurological research and his own model of mental evolutionism required a focus on the

${ }^{18}$ Crichton-Browne, op. cit., note 9 above, pp. 211-25.

${ }^{19}$ Cooter, The cultural meaning, op. cit., note 16 above, and Clarke and Jacyna, op. cit., note 16 above.

${ }^{20}$ Crichton-Browne, op. cit., notes 9 and 13 above. See also George Combe, Of the constitution of man considered in relation to external objects, Edinburgh, John Anderson, 1828. For his "own department" see James Crichton-Browne, 'Ethics and individualism in medicine', Br. med. J., 1897 , ii:990-7, p.995. This was his Introductory Address to medical students at Mason College, Birmingham, at the start of the new academic year.
${ }^{21}$ See John Leyland (ed.), Contemporary medical men and their professional work, Leicester, Office of the Provincial Medical Journal, 1888, pp.30-1. Crichton-Browne was elected Treasurer at the Royal Institution in July 1889, remaining in post until his resignation in 1926. The talented circle of friends and professors from his Edinburgh student days, and the key figures of his early career (e.g., Bucknill, Hitchman and Parsey) are also listed here (p.28).

${ }^{22}$ Only some archive material is available, op. cit., note 6 above. 


\section{Sir James Crichton-Browne (1840-1938)}

early life of human beings, from within the womb of the mother until about the age of ten, which would enable general practitioners, practising psychiatrists and government educationalists to recognize and, with luck, to reduce the overall incidence of mental disorder. $^{23}$

In terms of life and practice, Crichton-Browne, between his fortieth and eightieth year combined his Visitorship (where he must have seen a wide range of cases) with the promulgation of a version of prophylactic paediatric neurology: or rather a paediatrics that attended to the circumstances of infantile brains, and the environment that they inhabited, as the key question of psychiatry and its social relations. The history of the mother's own health, the child's diet, the child's objects, the correct mixture of brain-work and handwork (he admired both Froebel and Montessori), this was the area that Crichton-Browne established as the royal road to adult health. ${ }^{24}$

Once adulthood had been reached, and the periodicities of puberty and adolescence had been negotiated, his philosophy veered firmly towards the eugenical and selectionist. Not for him the undifferentiated, state-dependent populations which he saw as the outcome of the socialism of Karl Pearson. ${ }^{25}$ The echoes of bad heredity and inept child rearing do not receive a great deal of forgiveness in the published statements of Crichton-Browne. Indeed, the lunatic asylum was to be the repository for those whose brains were damaged and whose prospects were limited. Mental deficiency was to be described and its reproduction contained. Adult ideas of a second chance-above all divorce-were not approved, perhaps because a second chance would mean the keeping of misshapen heredities in the general population, with less, as he would almost certainly have said, of the "right sort of babies". ${ }^{26}$ Crichton-Browne's severity, as a psychological writer and publicist, increased with the age of the individual in keeping with the responsibilities that mature adults were meant to display, above all in healthy and monogamous marriage. In the world of the infant, in the tiny details of its sleep (a central topic), of diet, of nurturing the child during dentition and, above all, of avoiding overwork on the brain, of "brainforcing", lay the secrets of future health. Conservative in politics, Crichton-Browne was liberal in child-management. Rigidly determinist at the points of maturity and full heredity (and its crucial experiment, marriage), he was pliant in his paediatrics, insisting that "full advantage should be taken of the plastic epochs" of youthful brain growth, when "the foundations of character were being laid down". 27

James Crichton-Browne played with brio the part of the Carlylean Scotsman, the patriot among the Sassenach rogues. His absolute defence of Thomas Carlyle tells us what he himself made of biography and biography's relations to life. At any number of points, in

23 James Crichton-Browne, 'Education and the nervous system', in Malcolm Morris (ed.), The book of health, London, Cassell, 1883, pp.269-380. See especially 'Brain-Growth', pp.283-92.

24 Ibid., pp.342-64.

${ }^{25}$ For example, Sir James Crichton-Browne, 'An address on biology and ethics', Lancet, 1893, ii: 853-9, p. 855 especially.

26 Idem, From the doctor's notebook, London, Duckworth, 1937, p.160.
${ }^{27}$ Idem, op. cit., note 23 above. See also the report on his inaugural address to the Child Study Association meeting in Edinburgh, Br. med. J., 1914, i:1324-5. He equated psychological development and "educability" with direct physical development. "The period of youth was that of brain growth, and brain growth was a gradually diminishing quantity as life went on. The convolutional eruption in the fetus was prodigious, in the baby luxuriant, in the child moderate and in the adolescent imperceptible" (p. 1324). 
the lectures, the reminiscences and elsewhere, Carlyle "the prophet", as he called him, set the standard that others must aspire to. ${ }^{28}$ The three words that come closest to the centre of Crichton-Browne's philosophy might well be "the Scottish breakfast". His Scottish version of pastoral, with healthy Scottish schoolchildren, walking to the right kind of school, after the right kind of breakfast, before returning home to supper and exactly the right amount of sleep, is a backdrop to almost all his writings. From his very metropolitan addresses, in Regent's Park, Queen's Gate, and Hans Crescent, Knightsbridge, this was the ideal-type to which Crichton-Browne paid his homage and gave the accolade of true health. ${ }^{29}$ With his famous Dundreary whiskers (some of the last of their kind, thus the "Spy" cartoon) he can be detected, among the cigar smoke and the smell of claret (his club was the Athenaeum), turning an idea of Scotland into an idea of the social relations of psychology and health. This was the engine of his life and practice, hauling him interminably between Edinburgh, the English provinces and London.

\section{Wakefield}

The ten years that Crichton-Browne spent at the West Riding Lunatic Asylum at Wakefield were, officially, his crowning achievement. Appointed at the age of twenty-six, called away at thirty-six to the Lord Chancellor's Visitorship (in succession to Bucknill), he displayed a productive and administrative energy that is well recorded in terms of contemporary testimonials, published papers and subsequent historical assessment. Viets felt that his "real worth to the world was accomplished at West Riding", stressing the eighty contributions (seven his own work, sixty-two by staff at the asylum under his direction) in the Medical Reports, articles that preview the separation of neurology from psychological medicine. ${ }^{30}$ These six volumes (i.e. the West Riding Lunatic Asylum Medical Reports) can be considered, in effect, as the first six volumes of the forthcoming journal Brain, which he also helped found, and co-edited from 1878. ${ }^{31}$ An 1888 biographical note even suggested that he left Wakefield only "because his arduous labours were telling on his health". ${ }^{32}$ Given the subsequent career of travels, dinners, speeches and memoirs - much of it based on this intense decade of experience-the lure of a wider fame and better remuneration seems a more likely explanation.

The main sources for his time at West Riding include a number of his own annual reports to the Committee of Visitors, ${ }^{33}$ his own scattered memoirs and papers, ${ }^{34}$ several

\footnotetext{
28 See for example Report of Mansion House Meeting, 25 January 1893, in National Society for Epilepsy Archives at Chalfont Centre, p. 12 ("Carlyle as the great preacher or prophet of the century that is now hastening to its close").

29 See, for example, Sir James Crichton-Browne, Stray leaves from a physician's portfolio, London, Hodder \& Stoughton, 1927, especially pp.131-42, 'Thomas Carlyle's student days', and pp.288-97, 'Struggling Scottish students'. For the "good breakfast" notion see Sir James Crichton-Browne, What the doctor thought, London, Ernest Benn, 1930, pp.68-70, 'The feeding of high school girls'.
}

\footnotetext{
${ }^{30}$ Henry R Viets, 'West Riding 1871-1876', Bull. Hist. Med., 1938, 6:477-87, p.483.

31 Ibid., p.482.

32 Leyland, op. cit., note 21 above.

33 See Reports of the Committee of Visitors and of The Medical Superintendent of the West Riding Pauper Lunatic Asylum, Wakefield, Hicks and Allen, 1866 to 1876 (Metropolitan Library, Wakefield).

34 There is no complete bibliography. The six volumes of memoirs (Crichton-Browne, op. cit., notes 26 and 29 above, and notes 92 and 95 below) are the basis for parts of this text.
} 
Sir James Crichton-Browne (1840-1938)

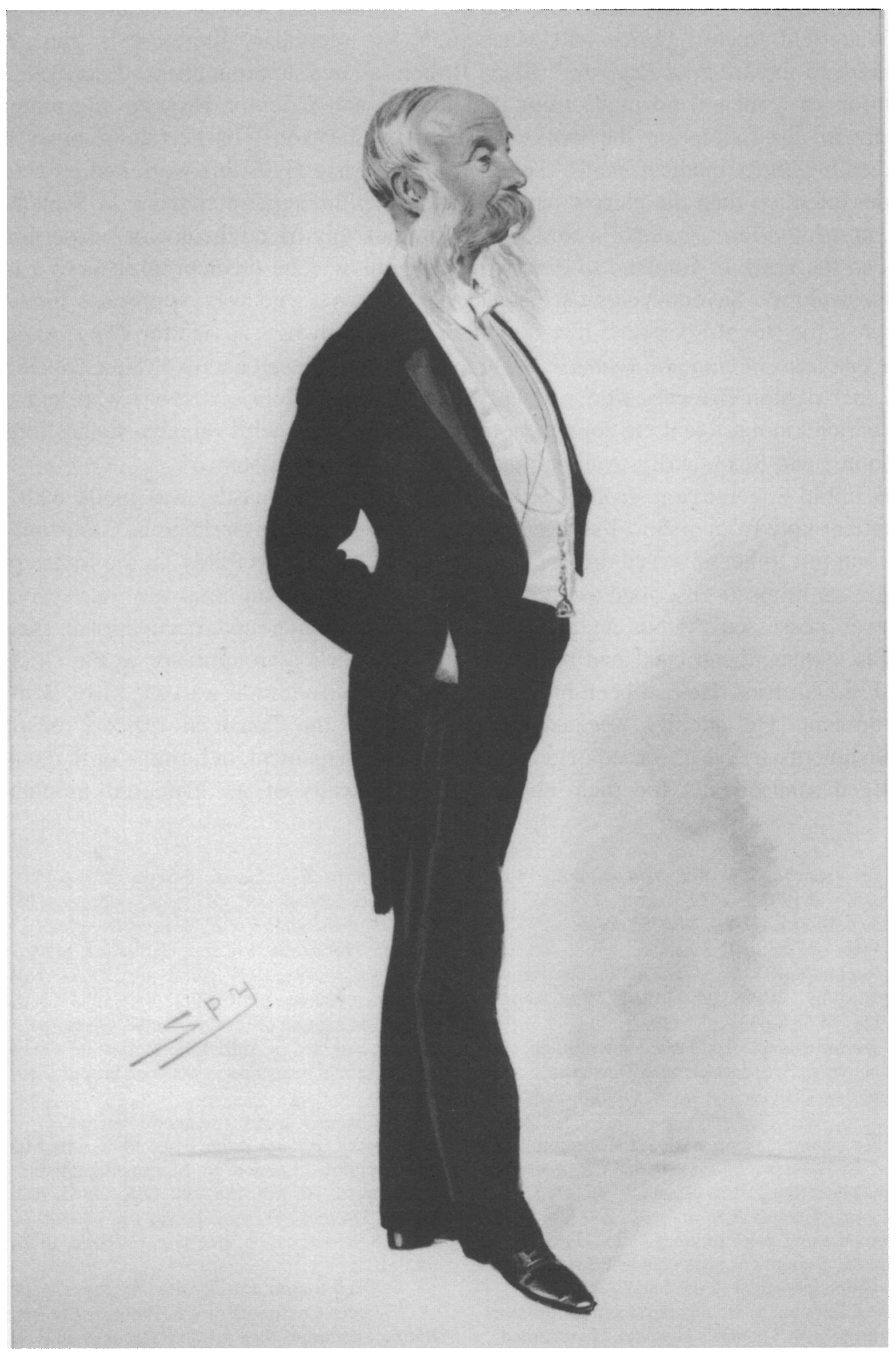

Sir James Crichton-Browne by Spy [L. Ward]. (Wellcome Institute Library, London.)

405 


\section{Michael Neve and Trevor Turner}

extracts from the Wakefield Express ${ }^{35}$ (the local weekly paper), and other miscellaneous files, including the medical casebooks and the 'Committee of Visitors' minute book' from the Wakefield Record Office and Museum. ${ }^{36}$ The secondary literature is thin. Viets summarized the Medical Reports. ${ }^{37}$ Shaw Bolton, a later superintendent, described 'The evolution of a mental hospital' from $1818-1928,{ }^{38}$ and Crichton-Browne intermittently appears in discussions on the work of Hughlings Jackson ${ }^{39}$ or Ferrier or other latenineteenth-century medical men. ${ }^{40}$ Yet, even in the early 1870 s, his work had attracted a broader attention than the narrow band of fellow asylum superintendents. In September, 1873, in All The Year Round, ${ }^{41}$ a contributor wrote of "my friend the doctor", describing a "visit to the north of England to dine with 'Horniblow', the medical director of a large county asylum". Several years earlier, Charles Darwin (who was to propose him as a Fellow of the Royal Society) ${ }^{42}$ had sought Crichton-Browne's advice for The expression of the emotions in man and animals. ${ }^{43}$ There are at least eleven detailed references in that book to Crichton-Browne, who was apparently "an excellent observer" who had with "unwearied kindness sent me copious notes and descriptions with valuable suggestions on my points; and I can hardly over-estimate the value of his assistance".

His initial appointment, from a previous position at Newcastle, was made with one dissentient vote from a short-list of eight applicants, including Dr Thomas Clouston, and was soon felt to be "in every respect satisfactory". 44 He had to follow in the footsteps of Dr Cleaton, himself described as "perhaps the most brilliant administrator our speciality has ever possessed", 45 but an active policy of rebuilding and occupational therapy (dances, games, theatricals) had been part of his father's own approach at the Crichton Royal in Dumfries. He had been brought up to see the asylum as a lively, busy, working environment. He tetchily rejected the notion that the "medical officers of these establishments are ... absorbed in general or fiscal management, in farming or in devising ill-judged amusements for their charges". ${ }^{46}$ By means of an increased number of

35 See especially the Wakefield Express, 14 Oct. 1871, p. 8 , and 19 Oct. 1872 , p. 2.

36 See Reports, op. cit., note 33 above.

37 Viets, op. cit., note 30 above.

38 Joseph Shaw Bolton, 'The evolution of a mental hospital-Wakefield, 1818-1928', J. ment. Sci., 1928, 74:587-633.

39 See for example Todd and Ashworth, op. cit., note 2 above, p. 396, and Kenneth Dewhurst,

Hughlings Jackson on psychiatry, Oxford, Sandford, 1982.

${ }^{40}$ For example, Humphry Davy Rolleston, The Rt Hon. Sir Thomas Clifford Allbutt KCB: a memoir, London, Macmillan, 1929, especially pp. 41, 57, 148 and 183, and The autobiography of Felix Semon, eds H C Semon and T A McIntyre, London, Jarrolds, 1926, p. 86. Semon was physician to Edward VII, and sometime president of the Laryngological Society of London, as well as physician for diseases of the throat at St Thomas's Hospital. He recorded visiting Ilkley in the mid-1870s and hearing a "truly brilliant speech" from a young doctor who "has since become the celebrated Sir James Crichton-Browne".
41 All the Year Round, 13 Sept. 1873, p.469.

42 See Leyland, op. cit., note 21 above, p.30. See also Obituary notices of Fellows of The Royal Society, 1936-1938, London, Harrison \& Sons for the Royal Society, 1939, vol. 2, pp. 519-21. This states that "he was elected Fellow in 1883, Charles Darwin being one of his proposers". Given that Darwin had died in April 1882, it must be assumed that there had been a delay between proposal and election.

${ }^{43}$ Charles Darwin, The expression of the emotions in man and animals, London, John Murray, 1872; reprinted London, St. Martins/Friedmann, 1979, pp.13, 76, 155, 185, 199, 205, 244-5, 292, 295-7, 314 and 341 , see especially p. 13.

44 See Reports, op. cit., note 33 above, 1866, pp.9-10.

${ }^{45}$ Shaw Bolton, op. cit., note 38 above, p. 606.

46 James Crichton-Browne, Preface, The West Riding Lunatic Asylum Medical Reports, 1871, i: i-iv. (There were 6 vols in all published between 1871 and 1876.) 
appointments (including a specific pathologist), by actively involving the local medical community, and by a constant practical approach to the need for new buildings, drains and baths, he created the space and atmosphere of a research-orientated institution.

How did he do it? An 1868 letter to the Journal of Mental Science outlined several mechanisms. ${ }^{47}$ Firstly, he employed, in addition to the regular staff, two clinical clerks who received "no salary, but only furnished apartments, board, etc. and instruction in mental and nervous diseases, in return for their services". These "ardent young men, fresh from the schools" exerted (he declared) a "vivifying influence" upon "the more confirmed asylum medical officers". Thus,

they rub off the rust of routine and create a necessity for vigorous reading. They afford, too, wonderful facilities for carrying out scientific investigations and careful treatment, while they are themselves undergoing the best preparation for subsequent asylum appointments, and even for general practice.

Of course, he warned, they had to be "wisely and cautiously chosen" and under the "paramount and summary authority" of the medical superintendent. Crichton-Browne also had plans for paying them $£ 50$ per annum "once the number of lunatics had reached 1300 ". He was persuaded that "even this small sum will enable me to command a very superior class of men, will render those appointed more contented, and will induce them to remain with me for twelve months". Signing off "in great haste", he appended a list of twelve "Regulations as to the Clinical Clerks", which included keeping careful records, attending all post-mortems, and exerting "what moral influence they can with the patients for their benefit". The subsequent careers of these young men have not been fully researched, although several did reach senior asylum positions. ${ }^{48}$

Such appointments had been mooted in his first report for 1866, convinced that "larger though scarcely more expensive medical staffs than those now generally attached to lunatic asylums will be required". He also obtained a chief female officer, the addition of female nurses to the sick wards, improved remuneration and education for the attendants and, eventually, by 1872, a full-time pathologist. His 1929 appreciation of William BevanLewis exemplifies how, as superintendent, he was "on the look-out for talent ... discerned his zeal and ability", made him "clinical assistant without pay", but "promotion was rapid in those days". Bevan-Lewis soon became medical assistant and then the regular pathologist (and finally superintendent).

The sanctioning of this appointment Crichton-Browne called "a somewhat momentous step in the march of scientific progress in the lunatic asylums of this country", detailing amongst the appointee's tasks research designed to "elucidate some of the dark points which are still so numerous as to make a Cimmerian gloom of cerebral pathology". ${ }^{49}$

\footnotetext{
47 Idem, 'The education, position and pay of assistant medical officers of county asylums' (correspondence), J. ment. Sci., 1869, 14: 599-600.

48 For example Dr Herbert Major succeeded Crichton-Browne as Medical Superintendent at Wakefield, while Dr Crochley Clapham eventually took over Grange Hall, Rotherham (a "private asylum for ladies") and became a Consultant Physician to Sheffield Royal Hospital.
}

\footnotetext{
${ }^{49}$ See Reports, op. cit., note 33 above, 1866, p. 23.; 1867 , p. 17 ; 1868 , p. 38 ; and 1872, p.27. For BevanLewis see Br. med. J., 1929, ii: 833. Interestingly Crichton-Browne in this "Appreciation", while describing the "warm friendship" and "invaluable assistance" of Bevan-Lewis in editing Brain, admits to doubts as to whether "the somewhat delicate, studious and retiring subaltern with keen Cymric sensibility" would be equal to "the task of Superintendent".
} 


\section{Michael Neve and Trevor Turner}

This generosity of language reflects a second major characteristic, probably best summed up by the term "showmanship". Crichton-Browne introduced a series of annual "conversaziones", gathering between 150 and 200 guests at the asylum for a lecture (at about 8 p.m.) followed by a general inspection of various stalls. Refreshments were available, the band played selections from Verdi, Strauss, etc. and carriages left at 11 p.m. The first, in October 1871, was shrewdly timed for the fourth day of the Social Science Congress in nearby Leeds. "A great gathering of medical men" as well as "professional and literary gentlemen" and a number of the "personal friends of the able and indefatigable Director" braved rain and muddy roads to hear Dr Anstie talk on 'The hereditary connection of certain nervous diseases with each other' ${ }^{50}$ They also saw photographs of lunatics, curios, woodwork, and Parisian bread-and-seed soup (a reminder of the concurrent siege of Paris). "About 100 gallons of 'laughing gas' were in readiness" for "any of the guests who might require it", but there was "only a poor demand", stated the Wakefield Express. At the following year's gathering (210 acceptances from 230 invited), during Professor Turner's lecture, the chairman actually slipped off the dais and had to be rescued by the speaker, whereupon Crichton-Browne cheerily led him off for "refreshments and stimulants" amidst general applause. The stalls included Pathological Specimens, Microscopical Preparations and Scientific Instruments. By 1875 not only could one inspect the brain of a chimpanzee, and a photograph of a "Group of Insane Hindoos', the visitor could also study "various forms of British Micro-Fungi", "anaesthetic ether" and "the view from Lemnos at 4 a.m. showing the Mont Blanc range of Alps (Mr Lennox Browne)" [sic]. ${ }^{51}$

West Riding was certainly, although not exclusively, a museum of madness, but grand events were also part of the inmates' diary. The 1875 "fête champêtre", which from 1872 had replaced the annual "pic-nic", was apparently "a great success". Upwards of 890 patients participated in it, made the round of shows, took tea alfresco and witnessed the fireworks. ${ }^{52}$ If we consider that the director was also lecturing at Leeds Medical School and publishing regularly in the British Medical Journal and the Lancet, ${ }^{53}$ it is not difficult to think of it all as a circus, with Sir James (as he was yet to become) the ringmaster to ambitious assistants, performing pauper lunatics and mollified magistrates. His angry comment about the "degradation of the huckster" may reflect some direct and local criticisms of his methods. ${ }^{54}$

By contrast, the details of his reports are consistent, sober, practical and firmly medical. In 1866 he described the loss of restraint ("a valuable remedial agent") and the "tedious monotony of asylum life". He was already insisting that "insanity as a physical disease must be studied in its physical and physiological relations and treated by those means (including vaccinations) which directly influence bodily organs and functions". The use of "medical records thoroughly and careful kept, post-mortem examinations invariably and exhaustively performed and therapeutic agents critically employed" were to him of

\footnotetext{
${ }^{50}$ See Wakefield Express, op. cit., note 35 above, 14 Oct. 1871, p. 8.

51 Ibid., 19 Oct. 1872, p. 2. For 1875 the details are selections from the published programme for the 'Medical Conversazione, $19^{\text {th }}$ November, $1875^{\prime}$ in the Yorkshire Records Office, Wakefield.

52 See Reports, op. cit., note 33 above, 1873, p.25.
}

${ }^{53}$ For example James Crichton-Browne, 'Hysterical mania', Br. med. J., 1871, ii: 113-14, 145-6; and idem, 'Simple melancholia', Br. med. J., 1872, ii: 403-6, 429-31; and idem, 'Conium in the treatment of acute mania', Lancet, 1872, i: 143-4, 182-3, and 217-18.

${ }^{54}$ Idem, op. cit., note 46 above. 
incalculable importance. ${ }^{55}$ This theme of medical treatment as being "too lightly esteemed and too easily abandoned" 56 was persistent, and accompanied constant problems with dysentery and impure water, an increasing asylum population (leading to the erection of a new South Yorkshire asylum), and a view of insanity as on the increase "wherever toiling brains most abound". 57 To him it was "dangerous to convert the insane poor into the objects of private speculation" and he lamented "the erroneous notions of insanity and that hostile feeling towards its victims . . . still existing in the lower strata of the public mind" 58 To him asylums had to become hospitals, not "convenient storage of heaps of social debris"; they should "subordinate safe custody and comfortable lodging to cure and scientific explanation". 59

But two words dominated his reports at Wakefield, "brains" and "drains". With both he constantly wrestled, searching out their secrets. His discovery of the source of an unpleasant smell beneath a rotten floorboard was described with as much zest as 'Cranial injuries and mental diseases'. ${ }^{60}$ A murderous assault on an attendant, whose head was apparently reduced to a "shapeless pulp", was regarded dispassionately as "a pure homicidal impulse, an analogue of epilepsy convulsing the mind instead of the muscles". In the same year he had installed Turkish baths which included "a fountain bath from which a forcible stream of water may be applied to the anus and rectum". ${ }^{61}$ By 1872 his doctors were engaged in "strict and uninterrupted supervision over closets, drains, sculleries", even though "the strain of life and labour in this busy region is certainly telling injuriously upon the brains and hearts of those who have to support it". ${ }^{2}$ It is not surprising therefore that in 1873 the conversazione should have had W B Carpenter to lecture on 'Recent advances on the physiology of the brain', for to Crichton-Browne it was clear that the "aetiology of brain disease is not so simple a matter. It is out of a flux of causes, physical and moral, often blended and inextricably commingled". While agreeing that "every tide of popular agitation throws up some wreckage upon our asylum shore", he could still suggest that "madness may have its roots in the drains". ${ }^{6}$

No description of the Wakefield years could be concluded without reference to the Medical Reports. ${ }^{64}$ They are nowadays honoured automatically, detailing as they do the first comprehensive evaluation of an asylum population by an approved scientific enterprise. The measurements made from the sphygmograph, the ophthalmoscope, the laryngoscope, Stohrer's electrical apparatus and Dr Major's "Tephrylometer" (from the Greek words for "ash-coloured" and "matter") comprised some 20 per cent of the publications. Another 20 per cent were studies of various treatments, usually pharmaceutical agents (e.g., morphia, ergot), but also other physical methods (e.g., cold water). Associated physical conditions or pure pathology made up about a quarter; another quarter were essentially neurological (with an emphasis on epilepsy and general paralysis of the insane) while the remainder included clinical descriptions, studies on animals and

55 See Reports, op. cit., note 33 above, 1866, pp. 17, 19 and 23.

56 Ibid., 1867, p.23.

57 Ibid., 1868, p.25.

58 Ibid., 1867, pp.16-17.

59 Ibid., 1868, p.27.

60 James Crichton-Browne, 'Cranial injuries and mental diseases', op. cit., note 46 above, pp. 1-26.
${ }^{61}$ See Reports, op. cit., note 33 above, 1871, pp. 22-3, 26-7.

62 Ibid., 1872, p.21; and 1873, p.15.

63 Ibid., 1873, pp.16-17.

64 Viets; op. cit., note 30 above, gives a detailed analysis of the contents of the Medical Reports. 


\section{Michael Neve and Trevor Turner}

more generalized overviews. Crichton-Browne edited every volume, his assistant Herbert Major co-editing the sixth (1876). He also contributed to every volume, adding a brief preface (from one paragraph to three pages), detailing the spirit of his approach, preceded by a suitable quotation from writers such as Berkeley, Shakespeare, Carlyle, Swedenborg, Lewes, or Fiske. ${ }^{65}$

The labour involved-he writes of "labourers in the field of nervous pathology" in the preface to volume 6-was immense. Dr Major's "Tephrylometer" was designed to measure the thickness of cerebral grey matter, but required a careful series of dexterous movements, and "the examination of a single brain" comprised "upwards of 220 distinct observations". ${ }^{66}$ Crochley Clapham weighed 1,200 brains, including separate assessments of the "C.P.M." (cerebellum, pons and medulla), and analysed them by sex, age, disease and religious persuasion. ${ }^{67}$ Roman Catholics were heaviest, Protestant Dissenters second, Church of England the least. John Lowe's experiments on electro-excitability were "of a very tedious and laborious nature" and "very carefully carried out, at the cost of much time and patience". ${ }^{68} \mathrm{He}$ even admitted that "the chiefly negative character of the results is, therefore, perhaps somewhat disheartening", but felt that more accurate machinery might nevertheless "elicit facts of greater importance". To perform urinological analyses patients had to be "placed under the care of special attendants, whose duty it was to collect urine". ${ }^{69}$ Estimating chlorides, urea, phosphoric acid and sulphuric acid by four separate complex processes, on three-day series of urines, required scrupulous, prolonged and patient attention.

Throughout the studies the regular references to Crichton-Browne's papers, his clinical experience and his suggestions left no doubt as to who was the guiding personality. Outlining work 'On the therapeutic value of cold to the head', W T Benham admitted that "other physicians'. . . observations agreed with those expressed by Dr CrichtonBrowne". ${ }^{70}$ Clifford Allbutt, an established Leeds physician at the time, referred to "the aid and encouragement I have received from Dr Crichton-Browne" in the opening paragraph of his piece on 'The electric treatment of the insane'. ${ }^{71}$ References to the Medical Director's own writing provided regular footnotes. Crichton-Browne himself, in the first preface, had bemoaned "the absence of any immediate stimulus to the arrangement and elaboration of the materials collected" and the "want of any ready channel of exposition". He wished the series to "conduce to the relief of suffering, the

\footnotetext{
${ }^{65}$ For example, before the Preface to vol. 3 there is a quotation from Carlyle: "For does not health mean harmony, the synonym of all that is true, justly-ordered, good; is it not, in some sense, the nettotal, as shown by experiment, of whatever worth is in us? The healthy man is the most meritorious product of Nature, so far as he goes. A healthy body is good, but a soul in right health,-it is the thing beyond all others to be prayed for; the blessedest thing this earth receives of heaven".

${ }^{66}$ Herbert C Major, "A new method of determining the depth of the grey matter of the cerebral convolutions', op. cit., note 46 above, 1872 , 2: $157-76$, on p.166.
}

${ }^{67}$ Crochley Clapham, 'The weight of the brain in the insane', op. cit., note 46 above, 1876, 6: 11-26.

68 John Lowe, 'On electro-excitability in mental and nervous diseases', op. cit., note 46 above, 1873, 3: 197-215, on pp. 196, 197.

69 John Merson, 'The urinology of general paralysis', op. cit., note 46 above, 1874, 4: 63-93, on p.69.

70 William T Benham, 'On the therapeutic value of cold to the head', op. cit., note 46 above, 1874, 4 : 152-78, on p.176.

${ }^{71}$ Clifford T Allbutt, 'The electric treatment of the insane', op. cit., note 46 above, 1872, 2: 203-22, on p.203. 
advancement of science, and the credit of the medical profession". ${ }^{72}$ Routinely he had to exclude papers, because of excess of material, although by the fifth volume (1875) a more cautious acceptance intruded. Thus, "to a few is it given to penetrate mysteries or to flash forth discoveries, but to many [it] is permitted to prepare the way for such enlightenment". ${ }^{73}$ The sixth and final volume pointed the way to the future, with accounts such as Sutherland's outline of 'Cases on the borderland of insanity' and his own long (sixty pages) paper 'On the pathology of general paralysis of the insane', adorned by his new title "Lord Chancellor's Visitor of Lunatics". ${ }^{74}$ But this world, of large cohorts of patients, careful observation and attention to methodological detail, also had its dirty laundry. Evaluation of one dietary treatment produced the astonishing figures of having reduced the supplementary wash, for one 52 bed ward, from 61 sheets and 86 shirts and 52 blankets per night, to 37 sheets, 45 shirts and 31 blankets per night. ${ }^{75}$ The social underside of Wakefield awaits its exposition, as does a detailed review of the impact of the work done there. Crichton-Browne's attitude to his work of measurement and evaluation, to the scientific enterprise in general, often seems ambivalent to the modern reader. Thus, writing in his ninety-seventh year (1937), he commented that it had been "science which crowed so lustily"; 76 yet he had previously agreed (1929) that "the system of public asylums" was "in a scientific sense a gigantic muddle", 77 intimating perhaps the failure of the asylum as a research base.

\section{Educational Interventions}

From his student days Crichton-Browne had expressed an interest in not just the culture of children but also in the 'Psychical diseases of early life'. ${ }^{78}$ This was the title of an 1859 paper to the Edinburgh Royal Medical Society, that was published in the Journal of Mental Science in the next year. Not only did he emphasize the formative impact of early training, but he also suggested that those children at risk included the off-spring of parents

\footnotetext{
72 Crichton-Browne, op. cit., note 46 above, p.iv.

73 James Crichton-Browne, Preface, op. cit., note 46 above, 1875, 5: iii.

${ }^{74}$ Henry Sutherland, 'Cases on the borderland of insanity', op. cit., note 46 above, 1876, 6: 108-19; and James Crichton-Browne, 'On the pathology of general paralysis of the insane', ibid., pp. 170-231.

75 John Merson, 'On the influence of diet in epilepsy', op. cit., note 46 above, 1875,5 : 1-23, on p.22.

${ }^{76}$ Crichton-Browne, op. cit., note 26 above, p.123. In this paragraph, subtitled 'Time's evolution', he complained that, "Science which crowed so lustily in the seventies of the last century, now coos gently as a sucking dove and admits there are immeasurables such as ideas and aspirations. ... consciousness is a part of nature and the highest part, and it is in it that evolution is going on today".

77 Rolleston, op. cit. note 40 above, p. 179.

78 James Crichton-Browne, 'The psychical diseases of early life', J. ment. Sci., 1860, 6: 284-320. This piece was considered a "tour-de-
}

force" in a modern review. See Alexander Walk, 'The pre-history of child psychiatry', Br. J. Psych., 1964, 110:754-67, especially pp. 758-9. See also Alexander von Gontard, 'The development of child psychiatry in 19th century Britain', J. Child Psychol. Psychiatry, 1988, 29(5): 569-88. It is also worth recalling that his father, in 'What asylums ought to be' had equated asylum treatment with child care quite directly. "In many respects an asylum should be assimilated to an infant school. The mind has been reduced by disease to the state of childhood; it displays the same waywardness, the same impatience of control and of compulsory labour, the same capricious desire for the gratification of the most urgent motive, and sometimes the same stubbornness and ill-temper. But while there exist similar difficulties, other characteristics of youth are present, which may be employed in this instance as well as in education to communicate strength, or to awaken powers that perhaps require only a proper stimulus to assume their legitimate exercise." (See Scull, op. cit., note 15 above, p. 193.) 


\section{Michael Neve and Trevor Turner}

who had broken "natural law" (i.e. who had been intemperate or self-abusing or attempted, and failed, at abortion), as well as those conceived under certain "moral influences". Children were also, of course, marked by hereditary predisposition, and this led Crichton-Browne to consider children as liable to suffer from any number of disorders; hallucinations; over-precocity; melancholia (leading usually to adolescent suicide); amentia and dementia; and a variety of manias including erotomania, theomania and pyromania (sub-classified as impulsive, epidemic or nostalgic). All of these were apparently possible pathologies in the life of children from the age of three onwards, but his concentration on early life is not surprising. It did however-in ways that bring out the anti-disciplinarian side of Crichton-Browne's paediatrics, in contrast to his later eugenism towards adults-involve him in some influential educationalist debates, the most important of which was the so-called "over-pressure controversy" of the $1880 \mathrm{~s}^{79}$

Partly making use of writings by medical men in Denmark (Dr Hertel, whose work he arranged to have translated and re-published) and Germany (especially that of Dr Treichler), and of Dr Francis Warner of the London Hospital for Children, ${ }^{80}$ CrichtonBrowne entered the controversies over education that stemmed from the Education Act of 1870 , and the reforms of Mr A J Mundella, pursuant to that Act, in 1880 and $1882 .{ }^{81}$ The issue related to the Board schools and Church schools organized since 1870, as well as the public elementary schools of England. It was suggested that the use of competitive examination and payment by results (schools being rewarded for the number of pupils who passed these exams), combined with the requirement for compulsory attendance, was producing an over-pressured school population, not least among the labouring poor. Just as important, for Crichton-Browne's purposes, was the later and resultant crop of diseased degenerates. Given his views on female brains and female education-that the brains of females were smaller and of lower specific gravity than those of males-Crichton-Browne saw the possibility of a weakened female adolescent population as a special anxiety. He claimed "every physician of authority on the diseases of women" as wishing for "a reduction and careful regulation of brain labour in girls from thirteen to sixteen years of age", warning of the "mischief to the individual and to society" resulting from "disregard of hygienic laws". $82 \mathrm{He}$ was subsequently to insist that "education from first to last can only be safely conducted in the light of cerebral physiology", and that over-pressure was "rampant in high schools for girls in this country today". He also felt strongly that "no girl

\footnotetext{
79 See for example Crichton-Browne, What the doctor thought, op. cit., note 29 above, pp.68-70, on 'The feeding of high school girls'; idem, op. cit., note 23 above, pp.342-64.

${ }^{80}$ See Crichton-Browne's Introduction to Hertel, Overpressure in high schools in Denmark, transl. C G Sörenson, London, Macmillan, 1885, especially pp. vii-xiv.

${ }^{81}$ For the context of these reforms, see J F C Harrison, Late Victorian Britain 1870-1901, London, Fontana, 1990, pp. 199-206; F M L Thompson, The rise of respectable society: a social history of Victorian Britain, 1830-1900, London, Fontana, 1988, pp. 135-51; Gillian Sutherland, 'Education', in F M L Thompson (ed.), The Cambridge social
}

history of Britain 1750-1950, vol. 3, Social agencies and institutions, Cambridge University Press, 1990, especially pp. 141-54. Two more contemporary contributions were Clement Dukes, Work and overwork in relation to health in schools, London, Percival, 1893, and A R Abelson, Mental fatigue: and its measurement by the aesthesiometer, Leipzig, Wilhelm Engelmann, 1908. An excellent and complex history of the social issues of this period can be found in José Harris, Private lives, public spirit: a social history of Britain 1870-1914, Oxford University Press, 1993.

82 See James Crichton-Browne, 'Sex in education', Br. med. J., 1892, i: 949-54, pp.949-50 especially, and idem, op. cit. note 80 above, p. xxviii. 


\section{Sir James Crichton-Browne (1840-1938)}

from 10 to 17 years of age should have any forced brain work to do after $7 \mathrm{pm}$, and that a reduction is required in the number of hours that high school girls are now called on to give to brain work". He described this as "anorexia scholastica", insisting that "buns in the morning" did not compensate "for a lost breakfast", and that "no girl who has shirked that meal should be allowed to go to school or engage in brain work". The resulting damage, he warned, would lead to "functional nervous disorders, which do not kill but cripple and perplex, and are often the source of misery long drawn out ... Woe betide the generation that springs from mothers amongst whom gross nervous degenerations abound!"83 Such concerns, as to the bitter fruit of the over-pressured primary state schools, led Mundella to invite him to make some enquiries into London's elementary schools and to submit a report to the education department. ${ }^{84}$

With characteristic zest, but perhaps a less than reliable methodology, Crichton-Browne visited fourteen public elementary schools in London (twelve board schools, two denominational ones) and his report, published in 1884, showed these were in the Walworth/Stockwell/Lambeth districts. While expressing an admiration for the 1870 Act, he went on to describe "unchecked evil which must be prevented". He felt that the use of competitive examinations, the detention of seven- to fourteen-year-olds, and the knowledge that most children arrive without breakfast were leading to "a rich crop of nervousness", to brain fatigue, to disease. In particular Crichton-Browne noted a statistical increase in cases of hydrocephalus in children over the age of five (itself related to fatigue). He insisted that nearly half the pupils he had seen suffered from habitual headache, and to a slightly smaller extent, from sleeplessness, choreic movements and stammering. In his view, public elementary schools were becoming breeding grounds of a range of later pathologies, including tuberculosis, insanity and suicide.

In an addendum to the report, which Mundella at first wanted to suppress, an experienced schools' inspector, Mr J G Fitch, alleged that James Crichton-Browne was slapdash in his methods and that some of his recommendations (school milk for example) were not necessary. ${ }^{85}$ There was also a clear hint, in Fitch's comments, that Crichton-Browne was opposed to the education of some of the children of the labouring poor because they were being examined beyond their "natural" capacities. Crichton-Browne's Galtonian thinking may indeed have left him open to this interpretation-that children of the residuum were holding able pupils back, artificially restrained by compulsory attendance and compulsory examination. On the other hand, much of his writing on the over-pressure debate also had the usual rash of Carlylean flourishes, such as denunciation of a civilization that has "run to tongue", breeding neurosis, fatigue, and a false sense of value.

The additional important point for Crichton-Browne was that the over-pressure debate was international. In his introduction to Hertel's Over-pressure in high schools in Denmark of 1885 he stressed "that in every country in North-western Europe there have been, of late years, some popular agitations on the subject of educational over-pressure and scientific protests against it and its attendant evils of a more or less emphatic character". He chose to introduce the translation of Hertel because it was in a relatively

83 Ibid., p.953.

84 James Crichton-Browne, 'Elementary schools', Parliamentary papers (Commons), vol. 61 (1884), (Accounts and Papers vol. 15), pp. 1-53.
$85 \mathrm{~J}$ G Fitch, 'Memorandum relating to Dr Crichton-Browne's report', pp. 55-79, printed together with the report, op. cit. note 84 above. 


\section{Michael Neve and Trevor Turner}

inaccessible language, thus emphasizing the pan-European scale of the debate. ${ }^{86}$ Sociological variations in the ways in which over-pressure presented-scrofula in public elementary schools, nervousness in schools of a "superior description"-did not invalidate Crichton-Browne's hostility to a certain "spirit of the age", with children forced into early careerist educational patterns, and then suffering nose-bleeds, anaemia, listlessness and (especially in girls) consumption. To him these children appeared as feeble adults, exhausted and pressed in early life and adolescence, and not permitted the right to be less learned but free from disease. ${ }^{87}$

This rather public episode showed Crichton-Browne in all his aspects-an enemy of the inculcator of false value, of artificial stress, of hostility to practical skills-while at the same time using a graded model of individual development that would, in his judgement, lead to a proportion of the adult population failing the test, falling at the jumps. These people would simply have to be branded as inferior. However, he also gave his adult life to the study, maybe even the security, of those whom his philosophy had separated from successful development. For example his involvement with the National Society for the Employment of Epileptics and the organization of epileptic colonies was extensive and active. In a 1910 speech, celebrating the twenty-first anniversary of the Maghull Home for Epileptics, he welcomed the fact that the home was to be "supplied with more plastic material in the children to be sent to the new section" and "he looked with importance on the medical inspection of school children, now happily established". 88 Nevertheless, his work on over-pressure was seen as too radical to be implemented, and his views on women's education were termed a "jeremiad". ${ }^{99}$ His allowing some children not to be forced into examination was perhaps a class-based prejudice against their being educated at all, a prejudice that subsequently broadened out into his hostility toward the education of women beyond the secondary stage. In 1892 he could denounce the University of St Andrew's (which had opened all its classes "in arts, science and zoology"to women as well as men), as having taken "a downhill step towards confusion and disaster". 90

\section{Crichton-Browne's Thoughts from a Commonplace Book}

A particular difficulty in our perception of Crichton-Browne is his longevity. In 1856 he heard Thackeray give a public lecture at Dumfries-about George III for a fee of 40 guineas - and some eighty years later Sir James himself was addressing the public in a viii-xi.

${ }^{86}$ Crichton-Browne, op. cit., note 80 above, pp.

${ }^{87}$ Idem, op. cit., note 80 above, see pp. xix-xxxviii. Crichton-Browne's call for the prolongation of childhood also had a Darwinian feel. "There is no better preparation for a stormy life than a tranquil and happy childhood, and sound policy should guide us to postpone as long as possible the entrance of our children on that struggle in which so much is to be required of them. But instead of obeying the dictates of sound policy we do exactly the reverse. We 'flush to anticipate the scene'. We force back the struggle for existence into our schools, $\ldots$ and lose not an instant in plunging our children into the vortex of nervous excitement. Instead of holding back, we spur on; instead of labouring steadily to build up a strong, stable brain, we are content to hurry up one specious-looking externally, but radically rickety and infirm" (pp. xxxix-xi).

${ }^{88}$ His speech was summarized, under the title, 'The treatment of epileptics', in the Medical Officer, 1910, 3: 47-8.

89 See, for example, Br. med. J., 1896, i: 422, a leader entitled 'Should women be educated?', referring to a piece by Crichton-Browne in the Englishwoman magazine, wherein he is felt to have shown "more eloquence than temper" in his "jeremiad" on the education of women.

90 Crichton-Browne, op. cit., note 82 above, p.954. 


\section{Sir James Crichton-Browne (1840-1938)}

different world, on BBC radio while his nonagenarian birthdays ("Sir James . . . who still enjoys good health") were being specifically noticed in the British Medical Journal. ${ }^{91}$ Our view of him is also distorted by his own aged perspective. Between 1926 and 1932 he published five volumes of "heterogeneous jottings, grave and gay . . . a doctor's diversions, scribblements swiftly indicted at halting places on the professional highway". Ranging from brief, one-line apothegms to five-page discussions on "the configuration of the brain", or the memoirs of "a bone setter", with an awful lot of Scottish anecdotes in between, these collections apparently derived from an old commonplace book. ${ }^{92}$ They do also contain biographical details, selected for the tastes of readers of the inter-war years. A construction of a version of his life from such sources requires considerable extrapolations. The amount of material, the constraints of memory and mellowing of age, contents praised as "a perfect treasure store for after dinner speeches", with "something for everyone of taste"-according to dustwrapper quotations from selective reviews-all make for considerable camouflage; we must also remember that "the doctor's casebook is locked in a drawer" and at times he will only admit to being in "Blankshire".93

The facts of the matter seem straightforward, despite the mistakes of several obituarists. The Lancet stated that 'More Leaves from a Doctor's Diary' was his last work, while the Royal Society obituary notice reckoned he had published "several volumes of reminiscences under the title 'Leaves from a Doctor's Diary', which had attracted considerable popularity". Crichton-Browne actually wrote Stray leaves from a physician's portfolio in 1927, and a later, sixth collection published as From the doctor's notebook in $1937 .{ }^{94}$ The former was exceptional in containing seventeen long speeches and pieces, from the Contemporary Review, Fortnightly Review, etc. The core popular works were Victorian jottings (1926)_deemed a most "appropriate Xmas present for friends" by the British Medical Journal reviewer, and perhaps therefore re-published with some additions as The doctor remembers in 1938, What the doctor thought (1930), The doctor's second thoughts (1931) and The doctor's afterthoughts (1932). ${ }^{95}$ Containing some 1,500 pieces, nearly 400 of which were medical/psychological in content, these make for irregular reading. Thomas Carlyle tops the order of references (36, including 3 for Jane). Burns is second (26), Scott and Shakespeare (16) tie at third. Lord Lister, Darwin, Huxley, Dewar and Barrie, amongst a host of standard Victorians, are also prominent.

The tone is very much that of the grand old man of medicine, looking back on a "long and distinguished professional career". After all, in his 1936 introduction to The chronicle

91 Idem, What the doctor thought, op. cit. note 29 above, p.151. See Br. med. J., 1936, ii:1177; and ibid., 1937, ii:1151, for his 97 th!

92 Idem, Victorian jottings-from an old common place book, London, Etchells and MacDonald, 1926, See Preface, p.v, "During my laborious years of professional and official work long ago I kept a Common Place Book, in which I scribbled now and then extracts from the books I read, apothegms, personal experiences, thoughts and speculations which I wished to remember. The entries in the Book are mainly of medical interest, more especially neurological and psychological, suitable only for the professional eye, but amongst these are interlarded jottings of a miscellaneous description which may perhaps bear repetition".
93 Idem, From the doctor's notebook, op. cit., note 26 above, see Preface.

94 For obituaries see Lancet, 1938, i: 406-7; Br. med. J., 1938, i: 311-12, and Obituary notices of Fellows of the Royal Society, op. cit., note 42 above, pp. 519-21. See also Crichton-Browne, op. cit., notes 29 and 26 above.

95 Crichton-Browne, Victorian jottings, op. cit., note 92 above; What the doctor thought, op. cit., note 29 above; and The doctor's second thoughts, London, Ernest Benn, 1931; The doctor's afterthoughts, London, Ernest Benn, 1932; The doctor remembers, London, Duckworth, 1938. The review of Victorian jottings is in Br. med. J., 1926, ii:1190. 


\section{Michael Neve and Trevor Turner}

of Crichton Royal, he introduced himself as the "Doyen of the Medical Psychologists of Great Britain"96 and in his books he was not averse to publishing letters in his praise. A 1909 specimen from a Dr Crozier congratulated Sir James on his letters to the press as a "pleasure to read", while his "speeches in the matter of public health" displayed "straight speaking, eloquence and authority, being calculated to do an immense amount of good". An 1871 letter, from Charles Darwin, on research into blushing, was quoted in full, starting "My dear Sir, your ms is invaluable" and containing further compliments. Darwin had concluded, more ambiguously though, with the words "many thanks for the dreadful photos of the imbeciles and for your very curious paper on psychical intoxication". In a reference to the Book of health (1883) and its editor, Sir Malcolm Morris, Crichton-Browne could write that this work contained "articles by all the leading London physicians of the day", not mentioning, of course, that one of the articles was a version of his MD thesis. ${ }^{97}$

The biographical details are also imbued with this tone. Sir James dined with everyone, from the "very lugubrious" Dorothea Dix at his father's table in Dumfries in the 1850s, to the Salford Sanitary Association in 1902 (at their Jubilee Conference in Manchester). He "adumbrated projects for the future of lunacy over frugal meals in Soho with Maudsley, Harrington-Tuke, Broadbent and Lockhart-Robertson" in the 1860s, and in 1916 "felt highly complimented when he sat next to Lady Randolph Churchill at a dinner in aid of the Great Northern Central Hospital". ${ }^{98} \mathrm{He}$ "fell under the spell" of Charles Dickens at an 1862 meeting at the Conservative Club, lunched with Arthur Balfour (in Dumfries in 1897) and was on the platform of the 1881 International Medical Congress when Pasteur's entry was greeted with spontaneous cheering. He dined "many times" at Lawn House with Dr Conolly, at the Athenaeum, at the Royal Society and, of course, at the Royal Institution. 99

Other associations crowd in. He was Lister's pupil in 1860 , and near neighbour in London in 1877, and throughout the 1870 s the "rendezvous of the intellectuals of the period" was at the St John's Wood residence of "my gifted friend, Charlton Bastian". 100 But every decade had its events, meetings, conversations. In 1860, when a medical student, his sister locked him in his room to prevent his seeing what was to be the last public execution of a female in Scotland. ${ }^{101}$ The victim was, tragically, a half-witted Irishwoman, yet as if by some prolonged process of compensation, by the 1870s he had witnessed over 600 post-mortems on the bodies of insane persons in Yorkshire. ${ }^{102}$ In the 1880 s he was even trying to commune with the dead, by partaking in telepathic experiments at the Society for Psychical Research, with Galton and others-and ruining them by his "offensive incredulity". He also attended the morgue-like Osborne House to receive his

96 Idem, 'Some early Crichton memories', Foreword to Charles Easterbrook, The chronicle of Crichton Royal (1833-1936), Dumfries, Courier Press, 1940, pp.1-6, on p.1.

97 Idem, Afterthoughts, op. cit., note 95 , pp.131-3; What the doctor thought, note 29 above, pp.61-4; Second thoughts, note 95 above, pp.231-2. For The book of health see note 23 above.

98 Idem, op. cit., note 9 above, p.200, and What the doctor thought, note 29 above, p.228.

\footnotetext{
99 Idem, Afterthoughts, pp.107 and 252; and Second thoughts, p.112; and The doctor remembers, pp.290-3, all op. cit., note 95 above.

100 Idem, What the doctor thought, op. cit., note 29 above, p.32; and The doctor remembers, note 95 above, p.78.

101 Idem, What the doctor thought, op. cit., note 29 above, pp.43-5.

102 Idem, "A case of gangrene of the lung: with remarks', Br. med. J., 1871, i:141-3, p.142.
} 
knighthood, a procedure dominated by the difficulties of kneeling and by the courtier's whispered "don't miss the cushion when you flop". 103

He began the 1890s at Finsbury Town Hall, giving an address on the tuberculosis question, a speech countered by a lunatic heckler who insisted that Christ was the only cure for consumption and "that the speakers that evening had also shown a cloven hoof". In 1897, he was checking out a haunted house with his nephew, but in 1899 he was involving himself with "experiments on the influence of low temperature on bacteria". ${ }^{104}$ The new century had lighter engagements. In November 1901 it was a controversy in The Times' letters page with Winston Churchill on "Peat Reek and Harris Tweed": in 1914, it was a chat with Ernest Shackleton; and, later, he was helping the National Service League by outlining the "physiological advantages from a system of rational training and discipline", and the "protection from hooliganism, syndicalism and other social aberrations". 105

The brain, education, eugenics, Scottish literature, generalization, doctors' lives and "good friends" were the primary themes. On his own profession-whatever that really was - he was surprisingly unforthcoming. He admitted that "none have risen to eminence in my department of medical practice who have not written something about Hamlet's madness". Apologizing for his fellow alienists' "irresistible impulse to buttonhole you and confide their diagnosis", he allowed that "the play should be a textbook of medical psychology". 106 On psychoanalysis, he was scathing. Decrying the Freudians' "dirty and dominating Oedipus complex", he pointed to "passages in Freud's writing capable of causing profound nausea" and despised the "mind undermining" that "ferrets out verminous reminiscences". "The difficulty about psychotherapy is to know when it ends and humbug begins". He did not deny its occasional usefulness, approving the author of Strewelpeter as "a genuine medical psychologist who stuck to the old-fashioned clean and wholesome psychoanalysis". Crichton-Browne gave good descriptions of mental states but while "medical men must occasionally elicit unsavoury truths . . . they need not go boring in search of veins of pruriency". He questioned whether recovery rates had increased since psychoanalysis was introduced and insisted that Freud resembled Socrates "as much as a toadstool does a British oak". 107

Crichton-Browne's true faith was the brain. "The brain-cell is an altar before which spiritual unions take place, a tabernacle in which the holy of holies is enshrined". "BrainRest" and "Brain-Building", and "highways in the brain", brainlessness and brainprovender and brain-rust-these are his favourite children. ${ }^{108}$ " A too severe or protracted

\footnotetext{
103 Idem, Second thoughts, pp.58-64 and 243; and Afterthoughts, p.23, both op. cit., note 95 above. Apparently at a previous knighting ceremony, "a gentleman in his agitation missed the cushion, and, being a heavy man, came down with his knees on the floor with a tremendous thud. It very much alarmed Her Majesty, who must have thought it was a bomb!"

104 Idem, Second thoughts, pp.93-4; and Afterthoughts, pp.175-84, both op. cit., note 95 above; and What the doctor thought, op. cit, note 29 above, p.171.

105 Idem, What the doctor thought, op. cit., note 29 above, pp.131, 212, and 253-4.

106 Idem, Afterthoughts, op. cit., note 95 above, pp.111-15. His own view was that "it is a dangerous
}

game to feign madness", and that Hamlet both "put an 'antic disposition' on" and "it got the better of his very susceptible disposition" (p.112).

107 Idem, What the doctor thought, op. cit., note 29 above, pp.248-9 and 227-8; Second thoughts, p.162; and Afterthoughts, pp.138-41, both op. cit., note 95 above; and op. cit., note 26 above, p. 90 .

108 Idem, Afterthoughts, p.161; Second thoughts pp.195-6, Doctor remembers, p.90, all op. cit., note 95 above; What the doctor thought, pp.45, 48 and 70; and Stray leaves, pp. 87-130 and 143-53, both op. cit., note 29 above. 


\section{Michael Neve and Trevor Turner}

strain . . . in those who have not casehardened brains . . may upset the balance of the brain". Poetic inspiration is related to "brain cells vibrating"; dancing (and deportment) has a "cerebral intimation of its movement", and "the day-school with its home environment . . . affords the best climate for brain-growth". Religious conversion, a "soulstroke" akin to shell-shock, is a "rearrangement of cerebral machinery from darkness to spiritual enlightenment with new pathways of cerebral activity". ${ }^{109}$ There are modern difficulties, of course. "Relativity and the Quantum theory impose a stress so severe" that the brain "is apt to snap under them", yet it is also a "mighty coherer attuned in its many parts for the reception of whisperings from all quarters of the universe" with "its functional activity . . . shimmering over its surface like the Northern sky". ${ }^{110}$

But the process of educating, feeding and resting this precious organ ("it must be handled very gently") ${ }^{111}$ was the heart of his naturalist enterprise. In his 1895 Cavendish lecture on 'Dreamy mental states', he declared that "Education ... on psychological lines must conduce to peace and stability in the higher nerve centres". Disordered brains could recover if "relieved from educational pressure and carefully nourished". The female "food-fads so rampant amongst us" were a particular problem. A piece on the "Feeding of high school girls' called for a "good breakfast" and "limited homework", and suggested that "all female education should strive to prevent degeneration and preserve intact this divine and beautiful endowment". ${ }^{112} \mathrm{He}$ quoted intelligence tests and other reports, presenting a consistently liberal position. "Young children should have plenty of sugar"; lying and stealing he regarded as normal stages of childhood; the retention of corporal punishment was simply a sign of inefficiency, a "painful blemish on our English educational system"; hours of sleep at public schools were far too short. This led him, oddly, to an uncharacteristic despair in his statement that "it is always safe to praise education, but much of it, so-called, is sheer waste of time alike to the teacher and the taught". 113

Perhaps this darker streak was only to be expected. Despite the chatty, anecdotal, racy and relentlessly positive gloss of his Thoughts, Crichton-Browne was a Victorian, steeped in eugenics, degeneration and an awful fear of being "on the same level as a Hottentot". The "Half-Mads" were a particular problem, for which "eugenism (the acme of evolution) must do something" and he drew an interesting historical link with the phrenologists whom he termed "The First Eugenists". To him, eugenics was "ethical selection, which like natural selection aims at the elimination of the less unfit and the preservation of the fit". It also affected his practice. An anxious mother, questioning her daughter's prospects after an attack of hysterical mania, regretted the doctor's own married status because "you would have done very well and, of course, being in that line, you wouldn't have minded

109 Idem, What the doctor thought, op. cit., note 29 above, pp.221, 165 and 200; and Afterthoughts, p.237; and Second thoughts, pp.237-40, both op. cit., note 95 above.

110 Idem, Afterthoughts, op. cit., note 95 above, p.17; What the doctor thought, note 29 above, p.145; and op. cit., note 26 above, pp.79-80.

111 Idem, op. cit., note 26, p.80.

\footnotetext{
112 Idem, Stray leaves, pp.42 and 26; What the doctor thought, pp.68, 68-70 and 98, both op. cit., note 29 above.

113 Idem, What the doctor thought, op. cit., note 29 above, p.246; Doctor remembers, p.260; Second thoughts, p.272; and Afterthoughts, pp.268, 157-8 and 90 , all op. cit., note 95 above.
} 
what has happened". ${ }^{114}$ All around him, "idiots, imbeciles and criminals seemed to go on propagating freely" and "modern civilisation" was diligently contributing to the mess. Even one of his pet hates, motor cars, "which waste more time than they save" were contributing to "homicides", "mutilation", "trepidations" and "racial deterioration". Worst of all, "two brave boys", his own grandsons, had died on Flanders' fields, one of them having been returned to the Front in a patently unfit state. ${ }^{115}$ His late comment that "we are running short of the right sort of babies" has a bitter edge, hinting also perhaps at the death during his childhood of a brother and a sister. ${ }^{116}$

In contrast to such darker tones, throughout the Thoughts there are persistent glimpses of the daily life of the medical profession. Crichton-Browne loved his trade and praised it extravagantly, writing of "sacrificial professional fervour" and seeing in Luke Fildes' portrait The doctor an overwhelming image of care even for the poorest child. ${ }^{117}$ Items such as 'Dr Maclaggan' and 'The early Victorian country doctor', an addition in the reprinted The doctor remembers, have a Trollopian touch. The strange embarrassments of payment for medical services, the praise for doctors from Johnson and R L Stevenson and Carlyle in a section entitled 'Laus medico'- "He is the flower, such as it is, of our civilisation"- the 'Via medica', 'The school doctor', and the many meetings with remarkable men, these are the connective tissues of his life. ${ }^{118} \mathrm{He}$ has his warnings, of course. "The young doctor of today . . . with his motor car and 500 panel patients" must beware for "hustle is the danger of the day". Why not "take a rest, live well, take a little whisky at bedtime and leave the Oxford Dictionary undisturbed on its shelf?" He quoted his friend Hughlings Jackson: "Why go on with all this plodding, feeling pulses, taking temperatures, testing reflexes and worrying about this, that and t'other things? If you want fame and fortune, invent a pill". 119

These memoirs might reasonably be judged a gallimaufry, a formless cocktail of porridge and prejudice and patients of the past. There is Professor Laycock, a "biological Socrates", who underwent an amputation-a terrible operation- "without uttering a murmur". He was Crichton-Browne's magister-hero, the "most original and inspiring" of his teachers, ${ }^{120}$ who wrote of a science that "leads to rational faith, utterly opposed to arrogant infidelity". There are the many "good and brilliant" friends like Felix Semon, Sir Charles Sherrington, the Rev. Sabine Baring-Gould and Sir Rider Haggard. There is alcohol in abundance, tea-bibbing and George Crabbe the poet "furtively swallowing a dose of opium so that he might not flag in the talk that was going on". There is Carlyle

114 Idem, What the doctor thought, op. cit., note 29 above, p.247; and Second thoughts, p.50; and Doctor remembers, pp.71-2 and 89-90, both op. cit., note 95 above.

115 Idem, Afterthoughts, op. cit., note 95 above, pp.50 and 145, and the dedication "In Cherished Memory of Two Brave Boys, C.V.C.-B. and G.W.T.".

116 Idem, op. cit., note 26, p.160; and idem, op. cit., note 96, p. 619 , where the details of his family are outlined. In fact four of Crichton-Browne's siblings died young (one before he was born), thus he would have attended funerals at the ages of 6,12 and 30 years.
117 Idem, What the doctor thought, op. cit., note 29 above, p.130. Fildes' painting was first exhibited in 1891.

118 Ibid, pp.140-2. See also, idem, Doctor remembers, op. cit., note 95 above, pp. 302-3, 217-19, 220-2 and 270; and idem, op. cit., note 26 above, p.61.

119 Idem, Afterthoughts, op. cit., note 95 above, p.172, 42 and 14.

${ }^{120}$ Idem, What the doctor thought, op. cit., note 29 above, p.15; and Doctor remembers, op. cit., note 95 , above, p.40. See also note 13 above, CrichtonBrowne's Henderson Lecture, in which he describes Laycock as "the ablest and most suggestive of the medical professors in the Edinburgh University of my time", pp.20-1. 
taking the water cure . . . "a prevalent delusion among chronic invalids". 121 There are jokes: "You should consult an alienist Physician", I said to him. "No, no", he replied. "An English doctor is good enough for me". Or, "An Irish bishop, after reading Gulliver's Travels, said he didn't believe a word of it". Crichton-Browne did acknowledge, though, that "humour and risibility varies as time goes on". ${ }^{122}$ Crucially, there are the tasks of life. "Much vice, many mental disorders and diseases, arise out of a deficiency of the psychovitamins; a) family affection, b) moral principles and c) religious belief". But this Godfearing physician, who could not go along with Maudsley's materialism, did have a clear vision of life's pathway. Those delicate children's brains, diligently tutored, fed and watered, infused with moral sense and religiosity, had a distinctive task. Nurtured nature would ensure that "when the time comes, they will mate wisely". ${ }^{123}$

\section{Minding Darwin's Brain?}

As Crichton-Browne's late life memoirs make clear, his view of psychoanalysis was distinctly resistant. The case made out by Michael Clark, as to the "rejection of psychological approaches" does retain some general truth with regard to Crichton-Browne, but wants modification. ${ }^{124}$ It is clear that Sir James did have a great deal of time for a psychological dimension to his subject. While feeling that "in general medicine, the asylum medical officer cannot be too proficient", he also felt that "everyone, lay or medical, requires some acquaintance with psychology in his passage through life". Thus, he could conceive

of a man learned in all the wisdom of the psychologians who would be a less successful asylum medical officer than one with quick insight, wholesome imagination and vivid sympathy who altogether ignored Freud and Hegel. There is a tactus eruditus in handling the morbid mind that only personal practice can confer. ${ }^{125}$

While this might have lacked the intellectual dimensions and neologisms of the psychoanalytic enterprise, he did nevertheless feel, for example, that Mrs Siddons, by playing the part of Lady MacBeth too well, was in danger of being deluded into believing she was Lady MacBeth. Hamlet, for Crichton-Browne, was mentally disturbed because he had feigned madness and then could not get out of the part. He was, like many in the neurotic or (in his term) "half-mad" second circle, trapped inside a neurosis, but one that was the outcome of a morbid modification of personality. ${ }^{126}$ Crichton-Browne wrote

121 Idem, Afterthoughts, pp.208, 230, 270, 200 and 187 ; and Second thoughts, p.254, both op. cit., note 95 above.

122 Idem, What the doctor thought, op. cit., note 29 above, p.227; Second thoughts, op. cit., note 95 above, p.236; and op. cit., note 26 above, p.172.

123 Idem, What the doctor thought, op. cit., note 29 above, p.164; and Second Thoughts, op. cit., note 95 above, p.104.

124 Clark, op. cit., note 7 above.

125 Crichton-Browne, op. cit., note 9 above, p.205.

126 Idem, op. cit., note 106 above; see also his Address to the Section of Psychology at the BMA meeting at Cambridge in August 1880, 'Circles of mental disorders-modern nervous diseases', Lancet,
1880, ii: $292-5$, in which he defined an "inner circle of insanity, marked off by an arbitrary and somewhat shifting line", wherein could be found "officially recognised lunatics and idiots", and outside of this "a second circle embracing a multitude of persons", with "concealed", "partial", "inoffensive" or "incipient" conditions. This second or "crazy circle" contained "hosts of eccentric, half-mad, crackbrained, and imbecile persons, who move about in every grade of society", their numbers indicated, according to Crichton-Browne, by the numerous suicides, crimes and "mad communications" to eminent figures, such as the Astronomer Royal who apparently had "a row of pigeon-holes" to store the daily correspondence from unappreciated lunatics" (p.292). 
extensively on that great Scottish theme, the double, usually in terms of a double or splitself, one part unknown to the other, but twinned and often sinister. An unhealthy imagination might lead the half-mad to take on a part-the part of a double-that could not be escaped.

But he did reject hypnotism, seeing it as "in itself" a disease, a "depraved state of the brain and nervous system", and he castigated Beard's hypnotist performances in London in 1881, deeming them fraudulent and unethical. ${ }^{127}$ He felt this was the wrong kind of theatre, describing the proceedings as "a performance which would have been contemptible at a village fair, but which was outrageous when brought forward in the guise of science". Crichton-Browne, like Pinel, was anxious to make theatre part of his therapy, but only theatre of the right kind. Drama was meant to "stimulate the imagination", and thus "cleanse the stuffed bosom of that perilous stuff that weighs upon the heart". ${ }^{28}$ Likewise, with the faculty of imagination which he discussed in his 1889 'Address in psychology', not only was this "a psychical power" with "hygienic uses" both necessary and beneficial, it was also the spring for certain novel outcomes, "a pioneer opening up new pathways in the brain", as in the case of religious conversion or the deep appreciation of works of art or great written works. But it depended on the individual case. Rejecting any notion of censoring "tragic events and the horrid turpitude of life", he felt that everything depended on "the way in which it is treated". Thus, "passing through the brain of a Walter Scott or a Dickens, such knowledge becomes purified and protective, and has nothing but a wholesome effect when so broadcast". However, "passing through the brain of an Aphra Benn or a Zola, it grows infective and deadly and disseminates a moral plague around", and such sentiments echoed his later remarks on Tolstoy's degeneracy and J S Mill's "passionless" intellect. ${ }^{129}$

This rejection of deviant therapies, as injurious to the brain, also held for what he called "Freudism". In two articles in the Lancet in 1920, Crichton-Browne saw the importance of psychical manifestations of insanity and even praised the relating of this to "early manifestations" of infantile experience. ${ }^{130}$ But his main case was that the "antirepression" method, that is to say the digging into the mythology of the self, was philosophically incoherent, because the material could not be repressed. He insisted that there was "no method by which a person can voluntarily remove from consciousness some part of his mental contents". On the contrary, in his view, it was all too present in the memory, thus causing the suffering of the patient. Furthermore, as a method, psychoanalysis was also cruel, since "rubbing a raw surface has not hitherto been found conducive to healing". The only way to ease the burden of suffering was to steer the attention into more diverting pathways through the standard practices of moral

127 Idem, 'Dr Beard's experiments in hypnotism', Br. med. J., 1881, ii:378-9 Correspondence. G M Beard (1839-83) was most famous for his promotion of "neurasthenia" as a specific and widespread form of mental disorder, e.g., A practical treatise on nervous exhaustion (Neurasthenia), New York, William Wood, 1880. For his hypnotism work see G $\mathrm{M}$ Beard Nature and phenomena of trance ("Hypnotism" or "Somnambulism"), New York, G I Puttnam and Sons, 1881.

\footnotetext{
128 James Crichton-Browne, 'The hygienic uses of imagination', Br. med. J., 1889, ii: 399-405, p.403. This piece was again an 'Address in Psychology', given at the Leeds meeting of the BMA. The famous Shakespearean reference is to Macbeth, Act V, Scene 3 , lines $40-44$, beginning "Canst thou not minister to a mind diseas'd ...".

129 Ibid., p.401 and 404.

${ }^{130}$ Idem, 'Notes on psychoanalysis and psychotherapy', Lancet, 1920, i: 1248-9 and 1296-7.
} 
management: examples included field-work, poultry-keeping and, of course, basketweaving; "much sound psychotherapy lurks behind the sweat of the brow". The antirepression method, in his view, like hypnotism, disconnected the disturbed mind from the environmental diversions that provided an alternative world, and also from the series of alternative nervous pathways that could be developed. Thus, anxieties could not be

enucleated like an encysted tumour. The only way to dispose of them is to think of something else, or to circle round them at an ever increasing distance in thought until they are lost sight of altogether, or to blunt the sensibility of the cerebral centres by sedatives and narcotics. ${ }^{131}$

If anything, the claim for internality was a likely source of damage, not relief.

Crichton-Browne also objected to the sexual nature of the purported internal world. He felt there was a risk that "in exploring for sexual rudiments, we may plant the seeds of the very growth for which we are in search, and delusions of a sexual or obscene character are about the most persistent and dangerous encountered in the insane". The influence of both hypnotism and psychoanalysis he thus saw as short-lived, because they failed substantially to divert from the source of disturbance and instead directed themselves at it "in contradiction of accepted principles", particularly the principles of the nervous reflex. Instead of the royal road to the unconscious, or the archaeology of the mind, CrichtonBrowne suggested, in what might be termed a moral manager's cliché, that the key was the "restorative influence of the personal intercourse of the physician with his patients", and "the direction of the thoughts into new channels". In all ways, Browne would have no truck with these suspect continental psychotherapeutic techniques which he saw not just as seducing degenerate patients, but as degenerate in themselves (as well as being ineffective and contradictory).

Perhaps most illustrative of Crichton-Browne's version of the world was his synthesis of Darwinism, traditional Christianity, practical social hygiene, neuropsychiatric research and the central human task of ensuring that children were properly brought up. This broad theorization emerged during his public addresses of the $1890 \mathrm{~s}$, and seems to have become crystallized during the Great War in his pamphlet on the German propagandist, General von Bernhardi, whom he saw as having "grossly misapprehended and misinterpreted Darwin's position". It was not that Crichton-Browne accepted Darwin in toto, on the contrary, in an 1892 lecture at the Royal Institution, on 'Emotional expression' he ventured "with the utmost deference", to suggest that Darwin's views should be "subjected to criticism and revision".

Crichton-Browne's account of the brain's powers, and the brain as a mediator of social values, involved him in a complicated intellectual journey which required allowing certain privileges to the brain and its functions, while at the same time avoiding the pitfalls of neuroscientific materialism. He was prepared to acknowledge Darwin's major role in research in this area, but insisted on criticizing Darwin's three principles of "Associated Serviceable Habits", “Antithesis", and "The Action of the Nervous System". ${ }^{132}$ Darwin's facts may have been unassailable, but those laws by which he sought to systematize them were, in Crichton-Browne's opinion, open to question. Since the appearance of The expression of the emotions in man and animals in 1872, there had appeared the work of

131 Ibid., p.1297.

132 Idem, 'Emotional expression', Notices of the
Proceedings of the Royal Institution of Great Britain, 1893 , vol. 13, pp. 653-67. 
Fritsch, Hitzig, Ferrier, Munk, Goltz, Schaefer, Horsley, Beevor and (not least) work on brain temperature by Mosso in Turin. This had advanced the scientific understanding of cerebral localization of function, with specific centres recognized as presiding over specific groups of muscular movements. The central region of the brain was seen as the great emotional area, yet extreme emotion could involve the whole motor area of the brain. "All through education, the process of specialisation goes on" and this sophisticated model of cerebral activity made Darwin's work anachronistic albeit admirable. ${ }^{133}$ Committed to "a pulsating brain which sent forth brilliant rays of psychical energy in periods of concentrated agitation or feeling", Crichton-Browne none the less announced a last proviso.

We are not one hair's breadth nearer comprehending the real relation between emotional and bodily states ... the further we pursue the parallelism between mental processes and neural changes, the more deeply convinced do we become that it is a perfect parallelism after all, and that we must reverently bow our heads in the presence of a great and inscrutable mystery. ${ }^{134}$

Such themes were further developed in his Address to Owens College in Manchester in 1899. While warning of those "indefatigable promoters of disease and degradation: overcrowding, overpressure, overdrinking, underfeeding, underbreeding, underthinking”, he nevertheless also warned against the "materialistic virus", Spencer's reduction of the species to "conscious automata", and the "three formidable giants who are always lying in wait to devour medical students-materialism, naturalism, and agnosticism". Summoning Carlyle (of course) to illustrate the "soul, bereft of faith-drowning slowly in quagmires of despair" (a barb at Henry Maudsley, perhaps), Crichton-Browne declared unequivocally that "there is an uncircumscribed physical universe of which we have no direct cognisance but in which we must believe". He then adduced Professor William James's "transmissive theory" to explain how brains were transparent places in the "mere surface veil" of the "universe of material things", through which "the outer sunlight of absolute light may shine". In Crichton-Browne's view there was a chasm between the organic and the inorganic, between the physical and the vital, and widest of all, between mind and matter. To him the highest, and ideal, task was "to quicken that spiritual sense that apprehends deeper relations than any that physical science can disclose". 135

Such flights of theory were often hidden, however, in his busy public activities after the turn of the century. His interests in nutrition, especially in child-feeding, were everywhere apparent. He considered, for example, that "a full and generous diet (especially proteid food) is the basis for individual and racial superiority". Denouncing "fads and faddists", he railed against "poverty and malnutrition", the "increasing prevalence of nervousness due to the strains of modern life", and related the rising suicide rate to "the spread of (over-pressured) education". ${ }^{136} \mathrm{He}$ was a leading light in the Society for the Prevention of

\footnotetext{
133 Ibid, p. 664. On Darwin's work see Janet Browne, 'Darwin and the expression of the emotions', in David Kohn (ed.), The Darwinian heritage, Princeton University Press, 1985, pp. 307-26.

134 Idem, op. cit., note 132 above, pp. 666-7.

135 Idem, 'The quest of the ideal' (Introductory Address, Owens College, Manchester), Br. med. J., 1899, ii: 902-12, see especially pp. 905-7, 909-10. For William James, see, inter alia, Gerald E Myers,
}

\author{
William James: his life and thought, New Haven, \\ Yale University Press, 1986. \\ 136 For Crichton-Browne's dietary comments see a \\ review of his pamphlet Parcimony in nutrition \\ (London, Funk and Wagnells, 1909) in Br. med. J., \\ 1909 , i: 1485-6. See Br. med. J., 1912, i: 1145, address \\ to The Child Study Society's annual conference, \\ wherein he suggested that "poverty of blood ... could \\ not be relieved by violent hockey"; and Br. med. J., \\ 1911, ii: 1434 for "nerves and nervousness".
}




\section{Michael Neve and Trevor Turner}

Venereal Disease, his black and white photograph was the illustrated frontispiece to a work entitled The rat problem, and he became involved in the obscure debate about the "electrification of babies". ${ }^{137}$ His memoirs were appreciated, and he used occasional tributes to old colleagues to reinforce his views. Thus he praised a certain Dr W R Hall of Leeds for his active role in the over-pressure campaign, not least because it seems "he shamed us by his demonstration of the superior hygienic conditions under which Jewish children are reared". ${ }^{138}$ Even when addressing 'The prevention of senility', a "good start in life", with "sufficiency of food and a sufficiency of teeth" (reflecting his interesting 1892 address on Tooth Culture) was seen as the real key, although "decent houses", promotion of "physical development" and "preventing over-use of the brain and nervous system" were also, it seems, of the essence. A critique of Henry Maudsley's materialist scepticism (about sanatoria and their effectiveness), addressed to the Sanitary Inspectors' Association, was typical of Crichton-Browne's drawing the lessons of faith even into the most practical arena of debates on social hygiene. ${ }^{139}$

But the "new theory of evolution" which he outlined in his critique on Bernhardi, ${ }^{140}$ was certainly the acme of his system of neuro-religious understanding. Reasserting Darwin's condemnation of war as anti-evolutionary (in contrast to Bernhardi's theory of war as purifying, as a "fundamental law of development"), and stressing the importance of "parental desire and parental fitness" in the key processes of natural selection and variation, Crichton-Browne nevertheless saw "a creative principle in the tree of life", an "inscrutable force", "an intelligent agency operating via a series of progressive interferences-call them miracles". He outlined "four tremendous mutations", which he deemed as revealing of "directivity, purpose and aim". These were the steps from the physical to the vital ("when God breathed into the first living thing the breath of life"), from the vital to the mental ("mind although rooted in brain stuff . . . can only bud, blossom and come to fruit when subjected to influences more subtle than any thus derived"), from the mental to the moral, ("social progress means the suppression of the ape and tiger") and, as the last and crowning mutation, from the moral to the religious. This final "epiphany" he saw as "an ascent from the moral sense to the sense of the divine", and as "the ultimate reality". Given this climax, he could state that there was thus "no contradiction between religion and science, for Evolution and Revelation will be synonymous terms". Such an elaboration of the themes previously outlined in his Owens College address was felt, by the British Medical Journal, "to deserve careful study,"141 but it should be noted that the piece was entitled 'PseudoDarwinism and war', and his pro-British denunciations of German unbelief may have been

\footnotetext{
137 For Crichton-Browne on venereal disease see, for example, Br. med. J., 1920, i: 241, 623 and 749-50, and Br. med. J., 1920, ii: 223 and 334. His photograph, as President of the Incorporated Society for the Destruction of Vermin, was in W R Boelter, The rat problem, London, J Bale and Danielsson, 1909. For "electrification of babies" see his remarks to the Child Study Association in 1914, op. cit., note 27 above, and Br. med. J., 1918. i: p. 321.

138 Idem, Br. med. J., 1923, ii: 952.

139 Idem, The prevention of senility and a sanitary outlook, London, Macmillan, 1905. His 'Address on tooth culture', Lancet, 1892, ii: 6-10, is discussed in
}

more detail below, see note 157 . It is of interest that John Hutton Balfour Browne (1845-1921), CrichtonBrowne's brother, was a lawyer and an authority on gas and water legislation. He lectured on "water supply" at the Royal Institution in March 1911.

${ }^{140}$ Idem, Bernhardi and creation; a new theory of evolution (an address), Glasgow, John Maclehose, 1916 , see especially, pp. $11-17,22-6,36,45-52$, and 61-7.

141 See Br. med. J., 1916, i: 562-3. This leader reckoned Crichton-Browne's argument to be a "crushing refutation of Bernhardi's fallacies", and went on to summarize the theories outlined above. 
the main source of its contemporary impact. Even the use of the theories of Immanuel Kant had to be racially justified by Crichton-Browne, who stated that Kant was, of course, "a Scotsman by descent", and thus "endowed with Scottish intellect". ${ }^{142}$

\section{Carlylean Connections}

However, in one important respect, Crichton-Browne may have been more of a continental modernist, more of an unconscious deployer of buried ideas of resistance, projection and defence than he cared to admit or understand. This is illustrated by his views on biography, or at least on one attempt at a memoir and biography, which bring out certain consistent themes in Crichton-Browne's life and practice. ${ }^{143}$

In his 1920 Maudsley lecture, the first of that series, he looked at the life of Henry Maudsley, his own differences with him, and his ideal versions of asylum practice. ${ }^{144}$ In the light of the experience of the First World War, with its revelation of a slowly degenerating population, Crichton-Browne renewed his call for education and eugenics, for asylum doctors who employed a psychotherapy that was "not an admixture of German frightfulness" but English, that is "chaste and approved". Equally striking, Crichton-Browne presented some images of recovery, recovery from shell-shock, from despair, from catatonia, that had the purpose in this lecture of adding an upbeat to the Maudsleyan downbeat. Recuperative changes occur in the "neurons, axons, dendrites or nerve-fibres of the brain"; heroism among soldiers was restored to itself, under the most brutal conditions; fear is defeated. Brains become unblocked; a soldier, silent since the day of battle, is cured by a bedside kiss; and Crichton-Browne turned, inevitably, to Tennyson for a poetic example. ${ }^{145}$

Home they brought her warrior dead:

She nor swooned nor utter'd cry:

All her maidens, watching said,

"She must weep or she will die."

Then they praised him, soft and low,

Call'd him worthy to be loved,

Truest friend and noblest foe;

Yet she neither spoke nor moved.

Stole a maiden from her place,

Lightly to the warrior stept,

Took a face-cloth from his face;

Yet she neither moved nor wept.

142 Idem, op. cit., note 140 above, p. 58.

143 Apart from the biographical details in his memoirs, his view of $\mathbf{J}$ A Froude's version of the life of Thomas Carlyle is essential to an understanding of Crichton-Browne's commitment to his much-quoted Scottish magister-hero. On doctors as biographers see, for example, William G Ober, Boswell's clap and other essays: medical analyses of literary men's afflictions, Carbondale, Southern Illinois University Press, 1979.

${ }^{144}$ Crichton-Browne, op. cit., note 9 above, see especially, pp. 211-13 and 217-18.

145 Idem, op. cit., note 9 above, p.218. The poem quoted from Tennyson is a lyric opening to section 6 of The princess: a medley, published in 1847, with additions in 1853 . 
Rose a nurse of ninety years, Set his child upon her knee-

Like summer tempest came her tears-

"Sweet my child, I live for thee."

Crichton-Browne, in pondering conversion in all its aspects, continued with, for him, a crucial final example, from Carlyle's Sartor resartus. ${ }^{146}$ Thus, Carlyle is walking along a street and is struck by a thought, "What art thou afraid of?" "And", he continues, "as I so thought, there rushed a stream of fire over my whole soul and I shook base fear away from me for ever. I was strong, of unknown strength ... I became a new man ... I authentically took the Devil by the nose".

The interest of these moments of conversion, these surges of power, is that they once again indicated the depth of Crichton-Browne's commitment to the world and the beliefs of Thomas Carlyle, who was for Crichton-Browne the philosopher of heroism, the genius who had tamed wayward German genius with the genius of Scotland, one of those prophetic individuals, capable of generating heroic thoughts, who lay outside the realm of biography and needed to be protected from the biographer. ${ }^{147}$ In this act of defence, one can see the heart of CrichtonBrowne's ideological system, the form of power that could not, in his terms, be omitted from psychological health but whose existence he took to be so persuasive as to generate extreme hostility to any who doubted it. An inspired free will could transcend cerebral injury and contradict determinism; such a free will was, more often than not, a product of accident, of the tangential, of the deflected. In the famous case of the treatment of Carlyle by J A Froude in his 1883 editing of Letters and memoirs of Jane Welsh Carlyle, certain controversial events took place that became celebrated in the history of Victorian biography and memoirs. ${ }^{148}$ Froude, historian, essayist, friend and editor of the sage of Cheyne Walk, had once been Carlyle's intimate. ${ }^{149}$ In two works of the early 1880 s, Thomas Carlyle's Reminiscences (1881) and the aforementioned edition of Letters and memoirs, Froude appeared to betray his trust and to reveal Carlyle in a shocking light. To put it simply, Froude alleged that Carlyle was domestically violent, sexually impotent (at least with his wife, Jane) and infatuated instead with one Lady Ashburton. This was evidenced partly by the degree of Carlyle's remorse, of which Froude made a good deal. It is of note that Froude went on to become Regius Professor of History at Oxford in 1892, although it is unclear how much academic kudos he obtained by this early version of psychohistory. Crichton-Browne subsequently intervened in the controversy, calling Froude's work a "kind of literary garbage", and seeing Froude as the friend who had betrayed and "was like a man driving a hearse". 150

146 Idem, op. cit., note 9 above, p.222.

147 See especially James Crichton-Browne and Alexander Carlyle, The Nemesis of Froude: $a$ rejoinder to J.A. Froude's "My relations with Carlyle", London, John Lane, 1903.

$148 \mathrm{~J}$ A Froude (ed.), Letters and memorials of Jane Welsh Carlyle, 3 vols, London, Longman, 1883.

149 See, for example, J A Froude, My relations with Carlyle, eds Ashley A Froude and Margaret Froude, London, Longman, 1903 and his edition of Thomas Carlyle, Reminiscences, 2 vols, London, Longmans, 1881.
150 See Crichton-Browne and Carlyle, op. cit., note 147 above, p. 122. See also Jane Welsh Carlyle, New letters and memorials of Jane Welsh Carlyle (annotated by Thomas Carlyle and edited by Alexander Carlyle) with Introduction by Sir James Crichton-Browne, London, John Lane, 1903, p. ix. Crichton-Browne pursued his case a decade later with his Preface to David A Wilson, The truth about Carlyle, London, Alston Rivers, 1913. 


\section{Sir James Crichton-Browne (1840-1938)}

But it was the nature of Crichton-Browne's opposition that is so revealing. In his role as alienist, Crichton-Browne set out the following case. Froude was mentally disturbed, as shown by his transferring feelings of exaltation into virulent hostility and by his "constitutional inaccuracy, flamboyant tendencies and proneness to preconceived ideas"; 151 this derangement was also shown by Froude's view of Jane Welsh Carlyle as mentally ill, especially in the period 1846-1855 and after 1863 when she was a morphine addict, suffering from neuralgia. However, to Crichton-Browne, it was also true that Thomas Carlyle was to be seen, himself, as an alienist manqué, heroically caring for his wife (whom Froude alleged had attempted to leave Carlyle at least three times) and whose accusations against himself were part of his nobility of temper and his "Titanic genius". 152 Carlyle's remorse was the remorse of greatness, not of degeneration. Thus CrichtonBrowne is recorded as actually absolving Carlyle "from all suggestion of cruelty or harshness", and describing him as "silken at heart like the Scottish Thistle". 153

Crichton-Browne saw Froude as locked in preconceived ideas, and thus made an interesting addition to the literature on the psychology of the biographer. By turning on Carlyle, Froude was viewed as turning on the source of that philosophical idea of resurgent power that Crichton-Browne believed to be at work in the regenerative examples he cited from the stories of mental patients, the cerebrally damaged, and the despairing. ${ }^{154}$ The double use of psychological and psychiatric categories - to render both Froude and Jane Welsh Carlyle as disturbed, albeit in quite different ways,- - sees Crichton-Browne as closer to a psychological, even a continental psychological, mode of defence (and, perhaps, repression) than he might have imagined. Carlyle became his double: the example of the caring husband who, at the same time, understood the mental illness of his wife and the diseased nature of his friend-turned-biographer. Biography, as a genre, might simply be the revenge of the mind gripped by preconception and flights of pathological flamboyance. Froude, in this analysis, becomes a patient of Crichton-Browne's, even as Carlyle becomes Crichton-Browne's superior. By taking this biographical approach, although this was in the $1880 \mathrm{~s}$, well before the perversities that Crichton-Browne was to denounce in the next century, he condemns Froude to the status of mental patient who has abused the philosopher who, for Crichton-Browne, spoke most powerfully of epiphany, of conversion, of recovery. Thus the title of Crichton-Browne's 1903 rejoinder repays emphasis. It has a classical fury in deeming Froude's work as hubristic-"The Nemesis of Froude" bespeaks Crichton-Browne's ferocious commitment to Carlyle's innocence.

\section{Conclusion}

In conclusion, James Crichton-Browne can now be placed inside the history of psychiatry's invisible role in later Victorian society, as well as inside the history of its

151 Crichton-Browne and Carlyle, op. cit., note 147 above pp. 123-8. In this context he also insisted that Carlyle's remorse was not self-accusatory but "noble".

152 Ibid., p. 66, where Crichton-Browne disputes Jane's wish to leave her husband. See also CrichtonBrowne, op. cit., note 150 above (Introduction), p. lxxxvii, in which Carlyle is deemed "the most purely Teutonic and grandly Titanic genius that has yet risen".
153 See Br. med. J., 1897, ii: 1606, a leader entitled 'Scottish education and Carlyle', and Crichton-Browne, op. cit., note 150 above, p. lxxxvii.

${ }^{154}$ See, for example, Crichton-Browne, op. cit., note 9 above. 


\section{Michael Neve and Trevor Turner}

intellectual and social elite, the network that included Athenaeum dinners, the Lord Chancellor's Office, the collaboration with Darwin, the (as yet unknown) visitations and their political implications. ${ }^{155}$ We can see Crichton-Browne as an acquaintance of Thomas Hardy, ${ }^{156}$ on his train, silently reading the periodical press, to all the world an elegant man of means, while hiding in his Gladstone bag yet another report on the secret life of a hidden Chancery lunatic. The conventional prejudices of his thinking are obvious: varieties of hostility to female education, to political radicalism, to the deep waters of infantile sexuality as both polymorphous and healthy. And the prejudices are encircled by a garland of Christian and Scottish chauvinism, a Buchanesque model of the rugged life that becomes a version, perhaps a slightly sinister version, of pastoral.

For there is a darker side to Crichton-Browne's analysis of late Victorian discontent. Even a routine address to a branch of the British Dental Association, could be used to conjure up complex and fearful imagery. ${ }^{157}$ Discussing the prevalence of dental caries, he blamed (as ever) the "softness and pulpiness of food", the impairment in nutrition generated by "high nervous tension", over-education "directly through interference with the growth and eruption of teeth" and townlife in general. "It is not an edentulous race that will finally possèss the world", he exclaimed, concluding with a Blakeian image of "the ghost of a lost tooth, a spectre of ivory pallor and hollow visage, with quivering fangs for limbs, wormeaten, writhing in agony . . . set to plague every dentist or doctor who has been guilty of denticide". ${ }^{158}$ These denunciations of "universal rottenness"-whether of teeth or the underclass baring them-find further exposition in his contribution to the peculiar debate on 'Dexterity and the bend sinister'. ${ }^{159}$ In a learned presentation to the Royal Institution concerning ambidexterity - to him "on a larger scale, impossible and undesirable",- -he "endeavoured to show that the propaganda of ambidexterity is not according to physiological knowledge, and that either handedness is not the charter of the coming man". ${ }^{160} \mathrm{He}$ detected traits of faddism in the movement- "some of those who promote it are addicted to vegetarianism, hatlessness or anti-vaccination"-insisting that "to try and undo dextral pre-eminence is simply to fly in the face of evolution". To him diminished right-handedness was associated with backward races, while ambidextral training he believed would "reduce the person submitted to it to a state of wobble". Reckoning there was a cosmic principle "regulating dextral and sinistral development throughout the organic world", he could even state that "ambidexterity" tended to

155 In 1896 Crichton-Browne was apparently invited to become Conservative candidate for the University of Edinburgh and St Andrew's, "in the event of a vacancy occurring by the elevation of Sir Charles Pearson to the judicial bench". Entering the House of Commons would have necessitated, it seems, his resigning the office of Lord Chancellor's Visitor, and in the event he did not do so for reasons that we have not been able to clarify. See Br. med. J., 1896, i: 801-2.

156 See, for example, William Greenslade, Degeneration, culture, and the novel 1880-1940, Cambridge University Press, 1994, p. 171, where it is reported that in August 1893 Hardy conversed with Crichton-Browne about differential brain sizes when they met at a "conversazione". See also Greenslade's reference 36 (p. 282) where he describes Crichton-Browne's place in latenineteenth-century psychiatry as "paradigmatic".

157 Crichton-Browne, op. cit., note 139 above.

158 Ibid., pp. 7 and 10 especially.

159 Idem, 'Dexterity and the bend sinister', Notices of the Proceedings of the Royal Institution of Great Britain, 1909, vol. 18, pp. 623-52.

160 Ibid., p.623. The "coming man" referred to a campaign some thirty years previously by the novelist Charles Reade (1814-84), in which he (according to Crichton-Browne) "denounced dextral pre-eminence as wicked and against nature". 
confusion; a society in which "two hands will be able to write on two different subjects at the same time ... must involve the enormous enlargement of our already over-grown lunatic asylums".161

As with his private comments in defence of the force feeding of suffragettes-justified since they were "temporarily insane" 162 - those not of his ilk were, essentially, mad. Feminists repaid the compliment. Discussing the tendency of masculine dictatorships to be renewed by war, Stella Browne spoke of reactionaries and their idea of the normal family, who initiated

a propaganda in which the licensed imbecilities of the pulpit are backed up by the venal and impertinent irrelevancies of the press and the pomposities of the debating platform, and stiffened by determined attempts to penalise (or at least to restrict) the sale of contraceptives to the poor.

Browne's specific example was Crichton-Browne's address at the Guildhall in October 1915 , which she reckoned a senile tirade. ${ }^{163}$ But he, of course, could use such language with what he would deem absolute authority, authority derived from Wakefield, his brain studies, his Visitorship and his intimacy with the scientific and social elite. ${ }^{164} \mathrm{He}$ could reassure them, in various versions, that their prejudices were scientific, their racial sensitivity justified, and their enemies deranged.

He had used a range of outlets to express his views, from the technical media such as the Journal of Mental Science, the Lancet, the British Medical Journal and Brain in the $1860 \mathrm{~s}, 1870$ s and 1880 s, to the more public platforms of the lecture theatre and afterdinner speech in the Edwardian era. After the War the memoirs adumbrated earlier themes, although the relative invisibility (in professional terms) demanded by his Visitorship had already pushed him into the role of a populist social philosopher. Furthermore, the trajectory, from diligent brain-weigher and neuro-psychiatric researcher to guardian of children's cerebral development, had an understandable though semi-secret logic. Intervening in psychopathology, by the time it had led to asylum confinement, was recognizably ineffective. His inner knowledge, that asylum care was, by definition, too late for many of its inmates, could not be publicly expounded. His task within the alienists' brotherhood was to keep up morale, enliven the conversazione and distract their (often neurological) critics by constantly elaborating a form of psychological expertise that kept ahead of the chase. He was the ghost in a machine of mental science who remains hard to recover historically.

161 Ibid., especially pp. 624, 635 and 652 . For the technical debate see also Anne Harrington, Medicine, mind, and the double brain: a study in nineteenthcentury thought, Princeton University Press, 1987.

162 See letter from Crichton-Browne to George Ives, 31 January 1914, from the British Sexology Society archives, in the Henry Ranson Humanities Research Center, University of Texas at Austin, miscellaneous section; correspondence of George Ives. Our thanks go to Lesley Hall for this and the following reference.

163 The comments of the radical feminist F W Stella Browne, can be found in Eden and Cedar Paul (eds), Population and birth-control-a symposium, New York, The Critic and Guide Company, 1917, in a footnote, p. 248.

\footnotetext{
164 For Crichton-Browne's social network, illustrative is the joint letter of congratulation to Herbert Spencer, in December 1896, offering "cordial congratulations" upon the completion of his System of synthetic philosophy. Among more than eighty names, including "Sir J. Crichton-Browne MD., LL.D, F.R.S.", can be found all those at the forefront of the exposition of scientific naturalism, as opposed to outright materialism, in Great Britain at that time. Included are Alexander Bain, $\mathrm{H}$ Charlton Bastian, $\mathrm{T}$ Lauder Brunton, George Darwin (Professor of Astronomy at Cambridge), Francis Galton, Sir Joseph Hooker, J Hughlings Jackson, E Ray Lankester, Henry Sidgwick, Leslie Stephen and Beatrice Webb. See David Duncan, Life and letters of Herbert Spencer, vol. 2, New York, Appleton, 1908, pp. 98-102.
} 


\section{Michael Neve and Trevor Turner}

But the commitment to the nurturing of the social brain, the brain as the expression of the means of containing social pathology and of forwarding social health, in this lay his strength. Furthermore, his commitment to the educational project, especially for children, was based on an admission. Hidden behind the slightly stagey geniality it may be considered that Crichton-Browne was indicating that the Wakefield years, and all the work there, and all the talk of science, had by and large been an exposition of the negative, the barest of advances, a small thing. It might also be proposed, against other interpretations, that this was not entirely explained by the career move from Wakefield to the Lord Chancellor's Office. A critic of a tired civilization, who did not shun eugenics, James Crichton-Browne emphasized paediatric hygiene over the difficult wedding of neurology and psychiatry. He was, in both its lightweight and rather darker versions, a doctor to society.

\section{APPENDIX \\ James Crichton-Browne and the Lord Chancellor's Visitors in Lunacy}

Details about this aspect of Crichton-Browne's life, that is between 1876 and 1922, can be found in a number of files, some of them only recently made available, in the Public Record Office at Kew. The files are initialled LCO, and the relevant ones are 9.4, 9.5, 11.2 and 11.3. Another extremely useful source is the evidence given by Lockhart Robertson and James Crichton-Browne in 1877, in their answers to the Select Committee on Lunacy Law, detailed in the relevant British parliamentary papers. It should be noted, however, that Crichton-Browne stated "I could not give a general assent to Dr Robertson's evidence", there being "many points of detail as to which I differ from him and many expressions of opinion in which I cannot concur".

Taking the Select Committee evidence first, it is noteworthy that Robertson, in particular, was questioned very closely as to the nature of his work as a Lord Chancellor's Visitor. Whether this was just part of the usual minutiae of parliamentary proceedings at the time, or whether it reflected a specific curiosity as to the workings of a somewhat shadowy office, is difficult to tell. There seems no evidence of deliberate evasion or hesitation in his answers, nor does he seem to refuse to answer any specific questions. From this oral evidence alone, a reasonable picture of the workings of the Lord Chancellor's Visitorship can be gleaned.

There were three Visitors, two medical and one legal. Robertson estimated that there were more than a thousand Chancery lunatics at the time, and the Board itself consisted of these three Visitors and two Masters in Lunacy. Other staff included a Chief Clerk and three clerks, based in Lincoln's Inn Fields. About a third of the patients were in private dwellings, and thus visited every quarter. Another two-thirds were in asylums and only visited annually. A report was made to the Lord Chancellor's Office after each visit and there was no intermediary between the Chancellor and the Visitors.

Whether or not an individual became subject to the Visitors was apparently "the mere accident of property". Thus, the relatives of someone deemed lunatic would present a petition to the Chancellor's Office, and an enquiry would be held at the relevant place of residence. This seems to have been largely a formality, Robertson stating that they were all "confirmed cases, almost all a question of property". As a result of this enquiry, an individual, called the "committee", would take charge of the assessed lunatic, also taking care of the individual's finances and arranging appropriate provision using this fund. 


\section{Sir James Crichton-Browne (1840-1938)}

The Visitors were assigned to one of three districts, on an annual basis. These were North, South, and West, and patients were visited by rotation. Special visits were arranged if letters from the committee about illness or patients' complaints were received. Robertson insisted that he "never gave notice at an asylum" prior to visiting. Furthermore, he only "occasionally" gave notice at a private house, and that was "to a few of the patients who are habitually out driving and walking; but it is not the rule; it is rather the exception than the rule". However, Crichton-Browne stated that in his experience "abuses are ever more likely to grow up amongst private cases than in the private asylum". He clarified this by stating "I mean single cases, boarding out, or residing in their own homes". He admitted that "even with the Quarterly Visitation, it is difficult to keep the custodians up to the mark". He also admitted that "the Visitors do not see the house until the lunatic is actually placed there and they make their first visit". In other words, they had no control as to where an individual was actually kept. At the time of his evidence in March and April 1877, he had been a Visitor for only fifteen months but, from his experience at Wakefield, he insisted that he could not "recollect one case in which a person has been sent fraudulently or out of malice or ill will [to the asylum]". Subsequently, he went on to state that at the time there were 1012 Chancery lunatics in care and also "the duties of the Visitors" were very laborious.

These statements are borne out by the archival records which also give more details of numbers and fees. Thus, new fees were introduced on the 1 April 1876 (not long after Crichton-Browne had begun working as a Visitor), giving expenses and a subsidy for travelling. This was two guineas per day, twelve shillings a day for a clerk and one pound and ten pence for each night. In addition, one pound was paid for each day when one was absent but "able to be home by night". Later, in 1890, it was stated "the existing scale does more than compensate for their actual expenses" (R Charlton Palmer). In the same record (11.3) it was stated that "the Visitors have no official hours". It was also mentioned, however, that "late visiting is necessary for the finding of patients and their committees or custodians at home, and essential for the efficient visitation of asylums and of private houses".

It seems the Board Meetings of the Visitors were held roughly monthly and, in general, everyone attended. Thus, on 9 June 1891, present were noted to be Lockhart Robertson, James CrichtonBrowne (JCB), Duckworth Williams and the two Masters, as well as R C Palmer (the legal Visitor). Seventy cases were referred and discussed and nine deaths recorded. On 7 July 1891, JCB is recorded as present, and he talked of lengthy correspondence and "promised to see the patient again". Apparently, Sir James "undertook to visit and report" and a month later (4.8.91) made his report to the Board and suggested that "two visits a year would be sufficient in future". At the meeting in November 1891, pensions were discussed, and on that of 1 December reports from 79 patients and two deaths were given. Letters from patients, the "committee", and doctors involved were all mentioned.

In general, the minutes are limited, and few patients' names are given. Between January 1892 and the end of 1899 , the following details are of note. For example, on 12 January, a "statement of receipt and expenditure for maintenance having been filled up in an unintelligible manner, and the committee's reply to the Board being unsatisfactory, the Chief Clerk was to write requesting him to call and explain". In February 1893, with Crichton-Browne in the chair, it is questioned whether monthly instead of quarterly accounts might be introduced. Concern about "fruitless visits" some three days after a change of residence is mentioned in August 1893, as is the Board's "attention to reports in the cases of Dead Lunacies awaiting to be cancelled". This did not prevent the Visitors finding out (4.2.94) that "the patient had been dead three months, no notice having been sent".

The circuits of the Visitors were also fixed at the Board Meeting. The arrangements for 1894-95 were for Mr Palmer (the Legal member) to do the Home Counties, Lockhart Robertson to do the Western circuit and JCB the Northern. The next reported change was for 1897-98, with CrichtonBrowne given the Western, David Nicholson (who replaced Lockhart Robertson) given the Northern and Mr Palmer given the Home Counties. For 1898-99, Crichton-Browne was given the Home 


\section{Michael Neve and Trevor Turner}

Counties, Nicholson the Western and Mr Palmer the Northern. Between forty and sixty cases were discussed at each meeting, each Visitor supplying about fifteen to twenty reports. Sometimes a Visitor's report was sent to the "committee", but between 2.4.95 and 14.1.96 Lockhart Robertson was away ill for much of the time, presumably putting quite a burden on Crichton-Browne. Thus, Sir James is mentioned as doing twenty-two reports in November 1895 but only twelve in June 1896 when David Nicholson had joined in place of the retired Robertson (he retired on 14.1.96). Few details of management are available, but on 3.12.95 it was noted that "the Visitor thinks the patient should be supplied with game from time to time".

The number of cases seen annually varied. In 1882 it was 1,142 , in 1889 it was 1,209 , but by 1896 only 960 . The numbers though had been gradually rising since the mid-1860s. A list is available (LCO 11.2) showing a total of 825 in 1866-7 (765 living, 55 deaths and 60 "new lunacies"), which had risen in 1880-1 to 1,148 (1,111 living, 33 deaths and 37 new lunacies). Overall figures are also available for the period 1891-3. In 1891 there were 2,604 visits made, 1,859 patients seen and 51,918 miles travelled (by all three Visitors together). In 1892, 2,340 visits were made, 1,777 patients seen and 44,902 miles travelled. In 1893, 2,350 visits were made, 1,752 patients seen and 47,604 miles travelled.

After the turn of the century details vary. Requests for special visits come in, and apparently involve "far greater amounts of work". Such patients apparently could not be seen "on ordinary rounds" for geographical reasons and because often they had to be seen urgently. Special journeys had to be made, and increasing demands were made on office work, and secretarial and clerical time. Crichton-Browne saw 70 special requests in the period 1909-10 (for Western), in the next year 153 (Home Counties), in 1911-12 he saw 78 (Northern) and in 1912-13 he saw 86 (Western). Figures for his co-Visitor, David Nicholson, were similar. The Home Counties always seem to have been the busiest circuit. In 1913-14, Crichton-Browne himself travelled 21,171 miles. In the same year, expenses are recorded for all the Visitors. Apparently, travel costs were $£ 1,306.19 .9 \mathrm{~d}$, and the approximate costs of administration were $£ 16,500$. The Treasury claimed fees of $£ 34,598$ and their profit was, therefore, nearly $£ 17,000$.

In the period 1913-23, special requests varied from 212 (1920) to 614 (1922). The average was about 300. The number of patients on the "permanent list" varied from 530 in 1913 to 600 in 1923. Each one required between two and four visits per annum. Thus, between April and September 1918, 643 visits were made to 611 patients and 25,827 miles were covered. Between 1 October 1919 and 31 March 1920, 742 visits were made to 623 patients, and 24,487 miles were covered. It was noted (10.11.23) that it was impossible to give the number of hours worked by each Visitor "as unless it was more than ten, no record is kept". However, it was suggested that each report took about three-quarters of an hour and about fifty reports a month were completed.

While sometimes up to twenty patients at a time could be seen at asylums, specific "one-off" personal visits clearly were needed. Assuming about 48 weeks of available time per year, and 5 days a week (i.e. 240 days), one can estimate that the Visitors probably spent at least three days a week travelling, perhaps more at times. Presumably, they tried to visit certain groups together by organizing their journeys, but there is insufficient detail in these archives to clarify this. While one must accept Crichton-Browne's statement that his tasks were "onerous", his involvement with so many other societies, institutes and dinners seems to suggest that this work and travel melded nicely with his other interests. He was even President of the "Incorporated Society for the Destruction of Vermin" which does not really seem related to the role of the Visitorship. It is difficult to imagine that Crichton-Browne would have worked for forty-six years in one post, until his eighty-second year, unless it had truly suited his purpose. In fact, one might suggest that the Lord Chancellor's Visitorship in Lunacy was perfectly fitted to his love of enquiry, of travel, of public activity, and of public pronouncements. 